\title{
SOCIOLINGVISTIČNI POSVET: AKTUALNI SOCIOLINGVISTIČNI IZZIVI IN PREDNOSTNE RAZISKOVALNE TEMATIKE
}

\author{
Maja BITENC, Marko STABEJ, Nataša GLIHA KO- \\ MAC, Matejka GRGIČ, Monika KALIN GOLOB, \\ Karmen KENDA-JEŽ, Albina NEĆAK LÜK, \\ Sonja NOVAK LUKANOVIČ, Krištof SAVSKI \\ Bitenc, M., Stabej, M., Gliha Komac, N., Grgič, M., Kalin Golob, M., Kenda-Jež, K., \\ Nećak Lük, A., Novak Lukanovič, S., Savski, K.: Sociolingvistični posvet: aktualni \\ sociolingvistični izzivi in prednostne raziskovalne tematike. Slovenščina 2.o, 9(2): 1-4o.
}

DOI: https://doi.org/10.4312/slo2.0.2021.2.1-40

Posvet o aktualnih sociolingvističnih izzivih in prednostnih raziskovalnih tematikah sta organizirala doc. dr. Maja Bitenc in red. prof. dr. Marko Stabej z Oddelka za slovenistiko. Potekal je v ponedeljek, 27. 9. 2021, na Filozofski fakulteti Univerze v Ljubljani in s prenosom preko Zooma. V prvem delu so vabljene strokovnjakinje in strokovnjaki predstavili svoje poglede ob izhodiščnih vprašanjih, v drugem je sledila razprava vseh sodelujočih. Objavljeni zapis posnetka so govornice in govorniki uredili po lastni presoji, načeloma s čim manj intervencijami, iz razprave pa so za branje prilagojene in objavljene vsebinsko tehtnejše replike.

Maja Bitenc: Spoštovane in spoštovani, drage in dragi, prisrčno pozdravljeni in pozdravljene na sociolingvističnem posvetu, na dan po evropskem dnevu jezikov, v živo na Filozofski fakulteti in na daljavo na različnih delih Slovenije in sveta!

Ob lastnem iskanju sem se z nekaterimi od vas že mnogokrat pogovarjala o različnih sociolingvističnih izzivih, o tem, kaj in kako je oziroma bi bilo najbolj smiselno raziskovati, večkrat pa sem ob tem pomislila tudi, da bi bilo dobro, lepo in prav, da bi se enkrat srečali skupaj in v širšem krogu razmišljali o prednostnih raziskovalnih tematikah, kot jih doživljamo ob svojem delu. Ob pomladnem izidu monografije Sociolingvistično iskrenje, v kateri so predstavljeni 
prispevki relevantnejših in tehtnejših raziskav, ki so nastale v procesu formalnega izobraževanja na Filozofski fakulteti, se nama je s soorganizatorjem današnjega srečanja, Markom Stabejem, zdelo, da je to pravi čas, pravi trenutek. Zelo naju veseli in sva hvaležna, da smo danes tukaj in da smo skupaj.

V prvem delu bodo torej na vrsti razmisleki vabljenih strokovnjakinj in strokovnjakov, v drugem delu pa bo čas za razpravo vseh navzočih. Morda se z Markom z namenom piševa Bitenc in Stabej, da imam po abecedi sama lahko tale uvodni nagovor, Marko pa bo, kot zadnji nastopajoči, zaokrožil prvi del.

Izhodiščna vprašanja za današnji posvet so torej:

Kaj so glavni aktualni izzivi za slovensko sociolingvistiko?

Kje in kaj se na področju sociolingvistike že dogaja in kako vrednotite to delo? Katere nove oziroma dodatne raziskave bi bile najbolj potrebne in v kakšnem okviru bi jih bilo najbolj realno oziroma smiselno načrtovati?

Seveda so dobrodošli tudi drugi relevantni poudarki, morda tudi glede četrtega vprašanja, če bi kdo želel, čeprav je usmerjeno bolj aplikativno: Kaj v sociolingvističnem smislu najbolj potrebuje slovenska jezikovna oziroma govorna skupnost v vsej svoji raznolikosti?

Če mi dovolite še nekaj vsebinskih pomislekov. Z Markom Stabejem sva se v zadnjem letu, ko je zorelo Sociolingvistično iskrenje, ki je bilo zasnovano v počastitev 90. obletnice rojstva Brede Pogorelec, lotila tudi pregledovanja in urejanja sociolingvističnih spisov te profesorice, ki naj bi izšli v zbirki njenih zbranih del. Ob branju se pogosto čudim, kako aktualne so njene misli in kako posrečeno zaobjamejo sociolingvistično situacijo in dinamiko. Breda Pogorelec je že sredi 6o. let izrazila pobudo za celovitejši opis govorjenega jezika oziroma govorov posameznih mestnih središč, kar se ji je zdelo posebej pomembno zaradi aktualnega uresničevanja norme formalnega jezika $\mathrm{v}$ praksi, predvsem v nekaterih medijih, kjer gre za posredno izvajanje jezikovnega načrtovanja, ter v osnovni in deloma srednji šoli. Prav v tistem času je William Labov, pionir sociolingvistike in proučevanja jezikovne variantnosti in jezikovnih sprememb, s svojo raziskavo dokazal, da so vzorci variantnosti, ki vodijo $\mathrm{k}$ fonološkim spremembam, $\mathrm{v}$ korelaciji s starostjo in družbenim razredom govorcev, obenem pa je obravnaval ozaveščenost njihovega govora. 
Takrat so se na primer začele tudi raziskave mestnih govoric na Češkem in Slovaškem in v 90. letih že doživele tudi svojo ponovitev, torej dopolnitev s sodobnim primerjalnim gradivom. Metodologija slovenskih sociolingvističnih raziskav dejanske jezikovne rabe in jezikovnih stališč pa se je v glavnem razvijala na področju slovenščine v stiku z drugimi jeziki.

Večino od vas je profesorica Breda Pogorelec verjetno učila, nekateri od vas pa ste učili mene in sem prav od vas prejela to, kar v strokovnem smislu sem, za kar sem hvaležna. Po dodiplomskem študiju angleščine in slovenščine, kjer sem z zanimanjem spoznavala jezika na različnih ravninah, sem bila obdarjena z možnostjo nadaljnjega študija in raziskovanja v okviru statusa mlade raziskovalke pod mentorstvom Marka Stabeja. Sociolingvistika me je hitro očarala - doživljala sem, da nadgrajuje vse moje dotedanje vedenje in ga povezuje z resničnim življenjem, s tem, kakršen jezik v resnici je in kar za nas, naše odnose in družbo v celovitosti predstavlja. $V$ široki svet sociolingvistike in raziskovanja stališč me je vpeljala profesorica Albina Nećak Lük, prva snemanja in analize sem opravila v okviru spoznavanja novejših metod dialektologije pri Karmen Kenda-Jež. Potem pa statistika, korpusno jezikoslovje in sociologija vsakdanjega življenja in imeli smo solidno podlago za doktorsko raziskavo, v kateri sem proučevala variantnost govorjene slovenščine pri govorcih z Idrijskega, ki delajo ali se šolajo v Ljubljani. Kvantitativno analizo izbranih variabel, predvsem fonoloških, smo prepletali s kvalitativno študijo socialnopsiholoških tem, kot so jezikovna stališča, jezik in identiteta, jezikovna ozaveščenost in izkušnje z jezikovno rabo. Po doktoratu in porodniški sem bila nekaj časa vpeta v sorazmerno sociolingvistična projekta na Oddelku za prevajalstvo pri Darji Fišer o akademski slovenščini in sovražnem govoru.

Možnost za nadaljnje delo na bolj mojem področju se je nato odprla v okviru podoktorskega projekta, kjer podobno zgodbo, kot sem jo pisala z Idrijčani, nadaljujem z Ribničani in Mariborčani. Razveseljujejo me stiki in intervjuji z ljudmi, mučim se z določanjem variabel in seciranjem glasov. Marsikaj je drugače in bolj zahtevno kot v doktorski zgodbi, ker sama ne pripadam skupnosti: težje je dobiti informante, nisem govorka ribniščine oziroma mariborščine, Mariborčanov, ki se vozijo v Ljubljano, je tudi relativno malo. Delo je večkrat precej samotno in bi si želela bolj stalno ekipo, občasno se sprašujem o smiselnosti početja in o nadaljnji poti. 
Zastavlja se mi vprašanje, ali bi bilo mogoče zasnovati oziroma izvesti celovitejšo raziskavo govorjenega jezika, po možnosti longitudinalno, kako in v kakšnem okviru. Da bi spremljali variantnost in spremembe ter relevantne socialnopsihološke teme na področju različnih narečnih skupin oziroma mestnih središč, tudi še naprej pri mobilnih govorcih - zaradi različne zgodovine, vloge, prestiža in statusa posameznih narečij namreč lahko za različne skupine govorcev pričakujemo različne ugotovitve. Za večjo zanesljivost in veljavnost rezultatov bi bilo zaželeno analizirati reprezentativnejši vzorec govorcev, transkribirati več gradiva in določiti variable na različnih ravninah ob fonološki torej upoštevati tudi morfološko, sintaktično, leksikalno, pa tudi prozodične lastnosti - tempo, ritem, melodijo govora. Dobrodošle bi bile tudi perceptivne študije, saj sociolingvistični pomen tvorijo vsi udeleženci v pogovoru. Tako bi dobili informacije o poslušalčevem vrednotenju variant oziroma varietet in njihovih govorcev, saj obstaja dilema glede razmerja med poimenovanjem in tem, kar posamezna oznaka predstavlja. Tovrstni podatki bi lahko osvetlili rezultate dosedanjih raziskav o stališčih do posameznih varietet in njihovi rabi. Tudi izkušnje s transkribiranjem kažejo na potrebnost nadaljnjih raziskav percepcije govora oz. posameznih variabel tako pri laičnih osebah kot strokovnjakih, ki zapisujejo besedila za znanstvene namene. Vključiti bi bilo smiselno tudi socialnopsihološke teme o jeziku in identiteti, jezikovnih stališčih, ideologijah, povezavi med osebnostnimi lastnostmi, stališči in jezikovnim prilagajanjem oziroma neprilagajanjem, o stereotipih in predsodkih, izkušnjah z jezikovno rabo in podobno. Posebej aktualna so vprašanja o odnosu do različnih jezikovnih varietet in njihovi rabi v konkretnih okoliščinah in situacijah, v katerih ima govor še posebej pomembno vlogo, recimo v vzgojno-izobraževalnih ustanovah, v podjetjih, v zdravstvu. Kot zanimiva področja, vredna nadaljnje obravnave, se kažejo tudi govor staršev in drugih odraslih z otroki, jezikovna raba v družinah, kjer starša govorita različni narečji oz. jezikovni varieteti, ter v družinah, ki so se preselile v drugo pokrajino, posebej pri otrocih iz takih družin.

Za proučevanje sodobne sociolingvistične realnosti, ki jo zaznamujejo mnoge in hitre spremembe, povezane z naraščajočo mobilnostjo, globalizacijo in novimi tehnologijami, ter za napredek sociolingvistične teorije bi bila potrebna integracija različnih jezikoslovnih, socioloških in socialnopsiholoških 
pristopov, znotraj teh mikro- in makroperspektiv, tudi etnografskih študij in analize diskurza. Vsekakor je dragocena kombinacija kvalitativnega in kvantitativnega pristopa, saj le na podlagi kvalitativnih raziskav in izsledkov lahko smiselno načrtujemo kvantitativne raziskave in smiselno interpretiramo njihove rezultate.

Kaže se, da bi bilo zaradi kompleksnosti in obširnosti področja pri morebitni obširnejši študiji potrebno vključiti strokovnjake z različnih področij, na primer dialektologe, fonetike, psihologe, sociologe, etnologe, računalničarje, strokovnjake za statistiko.

To je torej nekaj izsledkov, ki izhajajo iz mojega dosedanjega dela, sedaj pa predajam besedo vam, ki imate neprimerno več izkušenj in ste vpeti v delo različnih institucij, da problematiko osvetlite vsak s svojega zornega kota.

Vabim kar prvo govornico, docentko doktorico Natašo Gliha Komac, znanstveno sodelavko in namestnico predstojnika na Inštitutu za slovenski jezik Frana Ramovša pri ZRC SAZU.

Nataša Gliha Komac: Lepo pozdravljeni, spoštovane kolegice, kolegi. Najprej organizatorjema zares najlepša hvala za organizacijo tega posveta, ki ga po mojem mnenju slovensko jezikoslovje zagotovo potrebuje. Počaščena sem, da sem del tega omizja, hkrati pa moram priznati, da pogrešam še kakšen glas z Obale, Koroške ali Maribora, čeprav zdaj slišim, da je Maribor delno zajet in da imamo tukaj tudi kolegico s Koroške. Ta misel se mi je porodila, ker je to posvet, namenjen sociolingvistiki, in se mi zdi, da bi bila potem razprava res uravnotežena in bi bil $\mathrm{v}$ grobem pokrit celoten slovenski jezikovni prostor. Sicer pa čestitke, saj smo tu res predstavnice in predstavniki različnih pedagoških in raziskovalnih ustanov, raziskovalke in raziskovalci iz Slovenije in zunaj nje, predstavnice in predstavniki različnih starosti, poznavalke in poznavalci najrazličnejših področij.

Tri krovna vprašanja ste nam zastavili za razmislek. Moj je splošen - verjetno boste drugi bolj konkretni, a morda izzove kakšno konkretno, uporabno in iskrivo misel, idejo.

Sociolingvistika je eno tistih področij, ki nam je zaradi svoje prepletenosti z našim vsakdanom tako zelo blizu, da o njej vsi vse vemo in imamo navadno 
dokaj izdelana stališča. Morda so prav zato refleksija, strokovna razprava in argumentirano soočenje stališč toliko večji izziv. Jezik in družba sta nujno v navezi, saj je jezik sredstvo sporazumevanja, sredstvo identifikacije, ima svojo simbolno vrednost, svoj status in prestiž, prav prek jezika sleherni od nas sporoča svoje videnje sveta in družbe in jo hkrati soustvarja. In, na kar jezikoslovci vsake toliko radi pozabimo, tudi družba soustvarja in spreminja jezik oziroma vpliva nanj.

Prav zato je jezikovna politika vse prej kot naključna. Organizirane skupnosti navadno vedno premišljeno načrtujejo razmerja med jeziki, poskrbijo za njihove opise ter širjenje jezikovnega znanja. Sociolingvisti - raziskovalci in pedagogi - to stvarnost spremljamo, na dogajanje opozarjamo, razmerja med jeziki ozaveščamo, širimo znanje jezikov ter ga skupaj s stališči prenašamo na nove generacije.

In $\mathrm{v}$ tovrstnem celostnem razumevanju vidim glavni izziv slovenske sociolingvistike. $\mathrm{V}$ rednem spremljanju in opisovanju ter preverjanju tako imenovane slovenske jezikovne stvarnosti, v vsej jezikovni barvitosti in različnosti jezikovnih rab in praks. Pa naj gre za večplastnost oziroma tako imenovano družbeno zvrstnost slovenskega jezika in njegovo pojavljanje v najrazličnejših besedilnih vrstah ali razmerja med različnimi jeziki, njihovo dostopnost. Po vseh področjih rabe, zlasti javne.

In seveda ob zavedanju in odgovornosti različnih pristojnih služb, zlasti pa raziskovalk in raziskovalcev, pedagoginj in pedagogov, da s svojimi spoznanji, prenašanju teh v javnost, s svojim poučevanjem in usposabljanjem novih kadrov, tudi s svojim lastnim zgledom, rabo jezika, njegovih različic in različnih jezikov, do neke mere usmerjamo in določamo, predvsem pa opozarjamo na potrebo po razvijanju jezikovnih znanj ter zagotavljanju priložnosti za rabo. Kot je pokazala naša raziskava Jezikovna politika Republike Slovenije in njeni uporabniki (2017) in kot me v zadnjih dveh letih učijo izkušnje delovanja v različnih strokovnih odborih, zakonske podlage v večini so, in sploh ne slabe, nedomišljene, zalomi se pri uresničevanju določil in zavez. Včasih tudi zaradi njihovega nepoznavanja. Pri vsem tem so zelo pomembni programski dokumenti, za katere ni naključje, da se spreminjajo po določenem časovnem obdobju, in za katere je zelo pomembno, da jih spremljajo empirične raziskave, tako med splošnimi kot med specializiranimi jezikovnimi uporabnicami in 
uporabniki. Le tako so potem lahko politične odločitve, razporejanje finančnih sredstev ali celo na primer izobraževalni sistem res v duhu časa. In tu vidim izjemen pomen sociolingvistike kot stroke, ki spremlja tako razmerja in dogajanje v družbi kot tudi razvoj, trende in potrebe znotraj jezika, jezikov in jezikoslovja.

Mislim sicer, da se na področju slovenske sociolingvistike, tudi kar zadeva mednarodno vpetost, veliko dogaja, a morda preveč parcialno, razdrobljeno. Pogosto umanjka kontinuiran, celosten vpogled in pregled, redne in sprotne raziskave. $\mathrm{V}$ okviru različnih projektov nastajajo odlični pripomočki, opisi, nastavki teorij, a kaj, ko se včasih vse skupaj, na primer po štirih letih ali s še krajšim projektom, konča. Pa ravno se pridobijo ustrezne izkušnje, znanja, vzpostavijo se mreže in način dela ... In nato nekaj časa nič, potem pa nov razpis in zgodba steče od začetka, zopet se vzpostavi sistem itd., umanjkajo pa poglobljene analize. Ali pa drug za drugega preprosto ne vemo, premalo vemo o delu drug drugega in se stvari ponavljajo.

Pogosto se zdi, da ostajamo preveč zaprti vsak v svojem vrtičku, da zlasti pri večjih, bolj dolgoročnih in za širšo jezikovno skupnost pomembnih in odločujočih projektih premalo izmenjujemo in združujemo znanja in izkušnje. Konkurenca je vedno zdrava in kritična mnenja so izjemno dragocena, so pa odločitve in koraki, kjer je treba najti kompromise. In za uspešen vpliv v družbi in politiki, ki bo podpirala tako strateško jezikovno načrtovanje in spremljanje jezikovnih rab, praks, znanj in stališč ter razvoj tudi slovenskega jezikoslovja, je zagotovo zelo pomemben enoten glas stroke. Sicer je veliko enostavneje sredstva preprosto razbiti (in postopoma zmanjšati).

Pa še nekaj me občasno bega. Teoretični modeli - če odmislimo manipuliranje in slabe namene - pojasnjujejo stvarnost oziroma naj bi jo, vsaj po mojem razumevanju, razlagali in - v primeru sociolingvistike - (vsaj posredno) omogočali sporazumevanje in ohranjanje družbene stabilnosti, kohezijo, sobivanje, torej različnim jezikovnim uporabnicam in uporabnikom zagotavljali celostno in učinkovito sporazumevanje in delovanje v družbi ter posledično njeno soustvarjanje. Zato ne smejo biti zgolj sami sebi namen. Zato se zdi pomembno sprotno raziskovanje stvarnosti ter spremljanje dejanskih potreb, rab in stališč jezikovnih uporabnic in uporabnikov. A hkrati je pomembno tudi za zavedanje, da družba in jezik delujeta po nekih ustaljenih mehanizmih, ki so 
prenosljivi v času in prostoru. Nista od včeraj ter živita in bosta živela tudi v nekem drugem času in prostoru, brez nas.

Kot slovenistka in raziskovalka Inštituta za slovenski jezik Frana Ramovša, pa tudi kot neodvisna strokovnjakinja v odboru za Evropsko listino za regionalne ali manjšinske jezike pri Svetu Evrope, menim, da Slovenija potrebuje zlasti sistematično in kontinuirano spremljanje (slovenskega) jezika na vseh področjih javne rabe, to je v izobraževanju, sodstvu, javni upravi in javnih servisih, v medijih, na področju kulture, v gospodarskem in družbenem življenju, tudi pri čezmejnih izmenjavah. In sicer tako zapisanega kot govorjenega jezika, pri splošnih in specializiranih jezikovnih uporabnikih, seveda s posebnim poudarkom na spremljanju jezikovnih rab, praks in potreb ranljivih skupin. Pri čemer za dobre in aktualne jezikovne opise slovenskega jezika nujno potrebujemo aktualen jezikovni korpus z raznovrstnimi najnovejšimi besedili, poseben izziv pa je gotovo spremljanje slovenskega govorjenega jezika v vseh različicah.

Nujno je siceršnje sprotno spremljanje znanja in rabe jezikov ter stališč do njih v naši državi nasploh, in sicer zopet tako pri specializiranih kot splošnih uporabnikih ter s poudarkom na ranljivih skupinah in njihovem sporazumevanju. Včasih tudi zgolj in preprosto sledenje in iskanje načinov in poti uresničevanja zakonskih določb in zavez, ki bodo usklajeni s časom in aktualnimi potrebami jezikovnih uporabnic in uporabnikov. Predvsem pa njihovo sprotno preverjanje.

Pomemben je pretok znanj in izkušenj med raziskovalnimi in pedagoškimi ustanovami. Izkušnje učijo, da imamo raziskovalci na raziskovalnih ustanovah morda več priložnosti delati neposredno z gradivom, na terenu, pa naj gre za besedila ali na primer za različne terenske raziskave oziroma podatke s terenskih raziskav. Pedagoški delavci pa se neposredno srečujejo z zadregami študentov, z vprašanji, kako prenesti znanja v prakso ter tako neposredno odkrivajo, kje morda modeli in rešitve, opisi, ki smo jih na primer sprejeli avtorji različnih jezikovnih opisov in priročnikov, ne vzdržijo, niso ustrezni ali pa je potreben ponoven premislek, kako načela pojasniti. Zato mislim, da so izjemno dragocene mešane skupine, kjer sta mogoča prenos in izmenjava mnenj in znanj, predvsem pa se hkrati vzpostavlja medsebojno razumevanje in spoštovanje. 
In še čisto za konec: vprašanje smiselnosti in realnosti je vedno aktualno. Jaz bi ga morda zastavila nekoliko drugače: kateri so naši cilji, kam pravzaprav želimo našo »ladjo « pripeljati? Pri tem izhajamo iz realnosti, ki temelji na naših izkušnjah in znanju - vendarle smo se specializirali za to področje, hkrati pa jo nujno spremljamo z raziskovanjem potreb, rab in praks jezikovnih uporabnikov in uporabnic. In podobno je verjetno s smiselnostjo. Saj se verjetno lahko vsi poistovetimo, v kontekstu evropskega dneva jezikov, ki ga obeležujemo z današnjim posvetom, z željo po ohranjanju tako imenovane pregovorne »slovenske« večjezičnosti. Katere nujni del sta tudi znanje in raba slovenskega jezika. Hvala.

Maja Bitenc: Najlepša hvala! K besedi vabim docentko doktorico Matejko Grgič, sodelavko Slovenskega raziskovalnega inštituta SLORI v Trstu in Oddelka za prevajalstvo ljubljanske Filozofske fakultete.

Matejka Grgič: Hvala, lepo pozdravljeni. Moje izhodišče je slovenščina kot manjšinski jezik, predvsem slovenščina v Italiji. Ukvarjam se z jezikovnim stikanjem, se pravi z vplivanjem italijanščine na slovenščino, manj - oziroma skoraj nič - v drugo smer, torej z vplivanjem slovenščine na italijanščino. Ukvarjam se tudi z jezikovno marginalizacijo in z izključevanjem govorcev. Do nedavnega smo o tem, tudi na mednarodni ravni, veliko govorili v odnosu manjšinski-večinski govorci: govorci jezika, ki je na nekem območju večinski, so govorce jezika, ki je na istem območju manjšinski, izključevali iz svojih mrež. Vzrok in hkrati posledica tega je bila, da so govorci manjšinskega jezika zelo slabo obvladali večinski jezik in se zaradi tega tudi sami izključevali iz okolij, kjer se je zahtevala raba tega jezika. Danes opažamo že trend v nasprotni smeri, in to izrazito: nekateri mlajši govorci slovenščine v Italiji zase menijo, da slovenščino govorijo tako slabo, da se potem na primer ne odločajo za študij v Sloveniji - pravijo, da slovensko ne znajo dovolj dobro, da bi prišli študirat na primer računalništvo v Ljubljano, in to po trinajstih letih obiskovanja slovenskih šol. Ali to drži ali ne drži, je vprašanje, ki ga bo treba še raziskati, je pa dejstvo, da je taka percepcija zdaj že zelo močna. Trend se je začel kazati na področju branja: učenci niso več brali knjig v slovenščini, zato so se učiteljice začele spraševati, če so morda slovenske knjige bolj dolgočasne. Nakar so učencem dale Harryja Potterja, torej knjigo, ki je dostopna v obeh jezikih in katere vsebina je v obeh jezikih enaka. Večina otrok je rekla, da lažje 
bere v italijanščini - razen besedil, ki jih morajo nujno prebrati v šoli, učenci namreč sicer ne berejo v slovenščini: ne knjig, ne revij, ne objav na družbenih omrežjih. Isto velja za filme in vse druge vsebine, do naročanja hrane na dom. $\mathrm{S}$ tem je povezana tudi jezikovna variantnost - kako jo umestimo, kako jo razumemo, kako jo raziskujemo - in transverzalne teme: jezikovno načrtovanje in jezikovna politika, didaktika jezika in priprava jezikovnih virov - katere imamo, katerih še nimamo, katere bi potrebovali.

Zaustavila bi se pri nekaterih bolj aplikativnih vidikih. Na splošno se mi zdi, da raziskovalci veliko delamo, čeprav - tako kot je prej povedala kolegica - na nekih projektih z omejenim časom trajanja in financiranja, kar pomeni, da začenjamo na vsake tri leta stvari postavljati na novo. Včasih so viri financiranja tudi »neraziskovalni « in zahtevajo neke čisto druge cilje, namene in seveda končne rezultate. To pomeni, da je nesistematičnost ena od glavnih težav dela na tem področju. Vendar pa mislim, da je raziskovanje neverjetno dobro glede na dane okoliščine: ogromno raziskav imamo, če upoštevamo vse to, kar je bilo doslej objavljeno, in marsikaj, kar bo še izšlo iz današnjega posveta. Zdi se mi, da je veliko večji problem prenos teh znanj v prakso. Ko govorimo o znanju, ki je zdaj zbrano v tej predavalnici, in znanju kolegov in kolegic, ki nas spremljajo prek Zooma, in potem primerjamo, kaj se zgodi z vsem tem znanjem, opažamo, da je v najboljšem primeru to potem snov za kakšen izpit. Študenti in študentke se nekaj naučijo; eni bolj in drugi manj, eni se bolj napiflajo, drugi to bolj resno vzamejo v roke, a tukaj se zadeva v glavnem konča.

Ko sem pred kratkim pisala strokovni referat, namenjen odločevalcem, mi je Devan Jagodic, direktor SLORI v Trstu, rekel: »Matejka, zaključki niso v redu. « Pa sem rekla: »V katerem smislu niso v redu? « »Ja, v zaključkih moraš po točkah povzeti tisto, kar si prej povedala, ker bodo vsi brali samo zaključke. « Drugič bom torej na enem A4-listu povedala, kar pač moram, ni treba, da pišem članek, dolg 15 strani. Ampak tako pač je. Tu se mi zdi, da obstaja velik problem pri prenosu raziskovalnih rezultatov v prakso.

Za to bi dala še nekaj primerov. Mi nimamo, danes, dvojezičnih virov za jezikovni par italijanščina-slovenščina, slovenščina-italijanščina. Imamo Šlenca, Veliki slovensko-italijanski slovar avtorja Sergija Šlenca, ki je gigantsko delo, sploh če pomislimo, da ga je opravil en sam človek, a danes je slovar z več vidikov neuporaben, tako po naboru gradiva kot po obliki in metodologiji. Nič 
drugega nimamo. Opiramo se na EU-vire, ki so večjezični (torej ne specifični za jezikovno kombinacijo), toda to delamo profesionalni prevajalci - težko si predstavljam, da bodo ljudje, ki potrebujejo vsakdanje, hitre rešitve, iskali po Evrotermu, Evrokorpusu in tako naprej. To nekako ne gre. In tukaj nimamo nič: nič se na tem ne dela, nič se o tem ne govori in sploh ni nobenega načrta, da bi se to podprlo na ravni kakšnih bilateralnih zavez ali drugačnih, tudi aplikativnih projektov. Nič. Kot da tega problema ni. Pa je to problem tako za slovensko skupnost v Italiji kot za italijansko skupnosti v Sloveniji in seveda za druge uporabnike in uporabnice.

Drugo tako področje, s katerim se sama sicer ne ukvarjam, ampak ga srečujem in je problematično, je didaktika slovenščine na čezmejnem območju. Kolegica Nataša Pirih Svetina bo veliko več vedela o tem, a načeloma lahko rečem, da model »slovenščina je materinščina « na šolah s slovenskih učim jezikom v Italiji drži toliko kot ta čudovito lepa pravljica o materinščini nasploh. Tam so otroci, ki prihajajo iz zelo različnih družin, in tudi otroci, ki prihajajo iz slovenskih družin, a živijo v povsem italijanskem okolju. Ko gredo naročit sladoled, morajo sladoled naročiti v italijanščini. To pomeni, da se nikoli ne naučijo naročiti sladoleda v slovenščini. Zakaj ne? Zato ker naročanje sladoleda v slovenščini ni del učnih načrtov. Drugi problem je identifikacija z diametralno nasprotno definicijo »slovenščina kot drugi in tuji jezik «. Veliko otrok in mladostnikov obiskuje recimo poletno šolo slovenskega jezika v Ljubljani, ampak vsakič, ko se omenja sodelovanje tudi s Centrom za slovenščino kot drugi in tuji jezik, marsikoga zmoti že ime. Verjetno bo treba tu delati na področju neke specifične didaktike slovenščine kot manjšinskega jezika. Zdaj boste rekli: »Joj, še ena definicija. A bomo zdaj odpirali še en oddelek, še en center? « Ne vem, nimam dokončne rešitve, a dejstvo je, da je ta potreba zdaj že odprla čisto poseben segment dela. Ker so to, kako se ljudje identificirajo in kje se pozicionirajo, elementi, ki jih moramo upoštevati, ko govorimo o prenosu znanj v prakso.

$\mathrm{Z}$ didaktiko je povezano tudi pridobivanje novih govork in govorcev. Raziskave so pokazale, da se nobena manjšina ne ohrani, če se zgolj vzdržuje in ščiti. To je slovenska skupnost v Italiji skušala delati 50 let, tudi z zakonodajo, ki zagotavlja varstvo manjšinam in manjšinskim skupnostim. Dokazano je, da takšno varstvo seveda mora obstajati, a je to samo prvi korak; od tod dalje 
je potrebnih še veliko drugih korakov in eden od teh je pridobivanje novih govorcev. Pridobivanje novih govorcev je ključno. Na tem področju se dela absolutno premalo in nesistematično. Če vzamemo samo območje Trst-Gorica-Videm, torej obmejno območje, je zadnja raziskava o tečajih slovenščine kot tujega jezika, ki je bila objavljena leta 2015, pokazala, da je na tem območju tečajev veliko, a te tečaje izvajajo razna društva, večkrat tam poučujejo upokojeni učitelji slovenščine, študenti, člani društva ali pa kakšen entuziast. Mislim, da moramo biti, ne samo kot Slovenci, ampak tudi kot strokovnjaki in strokovnjakinje za to področje, malce bolj ambiciozni in moramo postaviti sistem - tako kot je prej rekla kolegica - sistematičnega raziskovanja in sistematičnega prenosa teh znanj v prakso: na primer sistematičnega pridobivanja novih govorcev. Verjamem, da je to veliko pomembnejše od zaščitniškega odnosa, ki ga imamo včasih do slovenščine v manjšinskem položaju. Veliko več bi naredili, če bi strokovno energijo in politični kapital vlagali v kaj drugega kot pa v varstvo manjšine in jezika.

$\mathrm{S}$ tem je povezan, nazadnje, odnos tako imenovane matice do manjšinskih skupnosti. Na vseh ravneh se, ko govor nanese na manjšine, veliko govori o ohranjanju. Letno imamo prireditev Dobrodošli doma, na katero so me enkrat tudi povabili, potem pa nič več, ker sem bila mogoče malo preveč kritična. Vedno se tam predstavi kakšna folklorna skupina ali pa kakšna pesnica ali pesnik - čim starejši seveda, iz čim bolj oddaljene vasi, kjer še edino on govori slovensko in piše poezijo v narečju, ki se ga spominja iz čim bolj oddaljenih otroških dni, ko je še z edino babico govoril slovensko. Tudi to je seveda del manjšinske realnosti, vendar pa ni slika celotne skupnosti. Danes zjutraj sem bila na Zoomu z učenci neke šole v Sloveniji, mislim, da so bili iz devetega razreda, in so spraševali, kako je s slovenščino v zamejstvu. »A vas veliko preganjajo? « je bilo eno vprašanje. »A imate še vedno folklorna društva? « Mislim, da je treba tukaj nekaj narediti tudi na podobi, imidžu manjšinskih skupnosti.

Za zaključek bi rekla tole: moje mnenje je, da se, ko gre za manjšinske skupnosti in sploh za ranljive govorce in govorke, zalomi pri prenosu znanj v prakso. V tem smislu, da znanja pridobivamo strokovnjaki in strokovnjakinje po znanstvenih metodah, ki so lahko boljše ali slabše, a imajo neko epistemološko podlago. Potem pa, ko se stvar prenese v prakso, ta kar naenkrat ni več strokovna, ampak postane ali politična ali diletantska - in tu imamo potem 
največ težav. Mislim, da moramo na tem še ogromno delati, in mislim, da smo tudi mi, kot strokovna, znanstvena skupnost, poklicani, da zahtevamo neke čim bolj konkretne odgovore in čim bolj konkretne ukrepe. Hvala.

Maja Bitenc: Najlepša hvala. Naslednja na vrsti je redna profesorica doktorica Monika Kalin Golob, predavateljica in dekanja na Fakulteti za družbene vede Univerze v Ljubljani.

Monika Kalin Golob: Dober dan vsem skupaj, lepo vas pozdravljam. Današnji nastop sem res bolj vzela kot posvet, zato nisem pripravila tako lepega besedila kot Nataša, ki je tako lepo nastopila in prebrala, zato bom malce improvizirala in se vnaprej opravičujem, če bo kakšna misel nedodelana. Ko sem razmišljala o tem, kaj danes povedati, sem o tem razmišljala kot jezikoslovka, ki dela zunaj matične fakultete, torej ne na Filozofski fakulteti, ampak na Fakulteti za družbene vede, kjer sem obkrožena z mnogo sociologi, politologi in samimi pametnimi družboslovci. Tako so se mi oblikovale tri točke, ko sem razmišljala o tem, kaj so prioritete, ki jih vidim kot pomembne za sociolingvistično razpravljanje, raziskovanje in poučevanje.

Prva se povezuje s šolo, torej poukom slovenščine, od osnovne šole do fakultete. Pri osnovni in srednji šoli - tudi sama imam trenutno doma maturanta - se mi zdi pomembno to, kar je kolegica Grgič rekla že za drugo didaktiko, torej, kaj danes učiti, kako danes osmisliti slovenščino kot učni predmet in učni jezik. Sama se s sinom velikokrat pogovarjam in me sprašuje: »Pa zakaj se moram to učit? « Nimam vedno dobrega odgovora. Če govorimo o raziskovanju, se mi zdi temeljni projekt o stereotipih o slovenskem jeziku, o tem, kakšen je danes odnos mladih do slovenščine. To je gotovo pomemben projekt, o katerem sva se s kolegom Stabejem nekajkrat tudi že pogovarjala, ampak nisva prišla kaj dlje od pogovora. $\mathrm{V}$ osnovni in srednji šoli se mi zdita pomembni predvsem vprašanji, kaj učiti otroka v šoli in kako, kar je seveda povezano ne samo z didaktiko, ampak tudi s tematskim okvirom prenašanja znanja. Na fakultetah se že dolgo ukvarjamo z vprašanji večjezičnosti, z vprašanji angleščine, z vprašanji jezikovne politike na fakultetah, a se pogovor vedno konča v nekem bipolarnem svetu. Svetu, kjer smo absolutno samo za slovenščino, in svetu, kjer absolutno podpiramo angleščino. In vmes iščemo rešitve, ki jih seveda lahko iščemo skupaj in v dialogu, ne pa v večni bipolarni razpravi, ki velikokrat meji na nestrpno razpravo, kot smo videli ob vsakem predlogu zakona, in se bo zdaj 
v kratkem ponovila, ko bo na mizi vnovič osmi člen Zakona o visokem šolstvu. To se mi zdi prvi pomembni sklop: šola na vseh stopnjah.

Drugo vprašanje zadeva odnos do jezika in ideologije, kar je tipično sociolingvistična raziskovalna tematika. Tukaj vidim tri podtočke, ki bi jih bilo smiselno raziskovati, predvsem pa osmisliti v praksi. Eno je trenutno zelo aktualna tema, to je sovražnost komuniciranja, ves sovražni govor, žalitve, vse to, kar spremljamo v naši politiki, in gre nato tudi naprej: iz političnega diskurza v širši slovenski prostor. Tukaj je nekaj raziskav, je nekaj idej, več kot to pa najbrž ne. Drugo je politični diskurz sam po sebi, torej vprašanje, kako raziskovati politiko. Imamo nekaj raziskav, kjer govorimo o tem, kako politiki nastopajo v parlamentu, ampak bi bilo to treba najbrž povezati s prejšnjim vprašanjem oz. ravnmi političnega diskurza. En del te sovražne jezikovne politike smo izkusili na lastni koži, ko ste tukaj na Filozofski fakulteti, potem pa še mi na FDV-ju govorili o spolu. Tudi to je tema, ki zelo razburja slovensko javnost, zato se zdi, da ideološke teme v slovenskem prostoru vedno naletijo na dvopolnost: ne najdemo dialoga in se vrtimo okoli dveh zelo nasprotujočih si argumentov, čeprav gre za poskuse ureditve problemov, ki so nujni za civilizirano družbo.

Vidimo torej, da gre vsepovsod za težko iskanje dialoga. In med razmišljanjem, kaj je krivo za to, sem prišla do tretje pomembne točke, in to je položaj slovenistike, položaj jezikoslovja pri nas. Ker tudi v jezikoslovju živimo zelo dvopolni svet, v katerem ne znamo iskati skupnih točk. Zanimivo je, da se to pozna tudi na odnosu družbe do nas: na FDV-ju smo jezikoslovke »lektorice«; nismo raziskovalke, nismo znanstvenice, ampak smo lektorice. Jezikoslovec torej pride prav, ko je treba kaj prebrati, kaj popraviti, kaj več pa tudi ne. Vprašanje spola, vprašanje politike in ideološkega diskurza lahko potem rešujejo sociologi, ne pa jezikoslovci. Tako da se mi zdi, da bi najprej morali opraviti nek metaslovenistični diskurz o tem, kako jezikoslovje danes funkcionira, kaj jezikoslovje je. Je to zgolj neko pomožno lektorsko znanje ali pa zgolj jezikovnosistemska zadevščina, ki potem ostane v ozkohermetičnih člankih in ne pride v prakso. Če bi to znali razrešiti, bi se potem tudi druge polarnosti lahko razreševale v strokovnem, znanstvenem in bolj smiselnem diskurzu, kot se rešujejo danes. Imam izkušnjo, ko smo delali nacionalne programe o jezikovni politiki, kjer se je res izkazalo to, kar je povedala že kolegica Grgič: strokovna ekipa lahko dela 
krasne dokumente, a kaj, ko ti dokumenti ne pripeljejo do denarja za postavke in se v petih, desetih letih seveda pišejo novi politični dokumenti, ki pa spet nikoli ne dobijo denarja, potrebnega za takšne projekte. Tako se mi zdi, da dandanes ni veliko optimizma, je pa veliko možnosti, da se s premislekom in temeljnimi projekti stvari tudi spremenijo.

Te tri točke so se mi izoblikovale ob hitrem premisleku: šola, ideološke teme in pa položaj jezikoslovja tukaj v Sloveniji. Zadnja bi potem od spodaj navzgor lahko rešila tudi drugi dve tematiki. Tako na hitro in hvala lepa.

Maja Bitenc: Najlepša hvala. Doktorica Karmen Kenda-Jež, višja znanstvena sodelavka in vodja dialektološke sekcije Inštituta Frana Ramovša pri ZRC SAZU.

Karmen Kenda-Jež: Pozdravljeni. Sama se bom osredotočila na eno samo točko, in sicer si to pravico jemljem kot tako rekoč edina priučena sociolingvistka tukaj. Odkar se ukvarjam z dialektologijo, sem - tudi na pobudo jezikoslovne misli Brede Pogorelec - vstopala v sociolingvistiko predvsem skozi iskanje najbolj primerne metodologije in tehnik za raziskovanje govorjenega jezika. O tem se namreč vsaj v našem prostoru, v dialektologiji na začetku mojih terenskih raziskav ni veliko razmišljalo. Zato sem še vedno najbolj povezana $\mathrm{z}$ variantnostnim jezikoslovjem in $\mathrm{z}$ vsem, kar se je $\mathrm{v}$ njem dogajalo od Labova naprej. Pri tem pa me ves čas muči razmerje med dialektologijo in sociolingvistiko v slovenskem prostoru.

Pred leti sem o tem napisala članek, ki je ostal v predalu, in prav vesela sem, da mi danes tega članka ni več treba dokončati, saj je imel naslov Prevzetnost in pristranost. Vendar se mi vseeno zdi, da to razmerje še vedno temelji na nekakšnem nesorazmerju, na implicitnih sodbah, ki bi jih za drugo polovico prejšnjega stoletja lahko opredelili kot dve predpostavki. Prva je bila - seveda ne govorim o celotnem jezikoslovju, ampak o tistem, ki je bilo v času mojega študija paradigmatično - da dialektologija ne spada med vede, ki se ukvarjajo s sodobnim jezikom. Druga pa, da empirične sociolingvistične raziskave navadno ne upoštevajo zemljepisnih posebnosti jezikovnega gradiva. Iz njiju sta se izoblikovala dva aksioma, ki še vedno obstajata, morda bolj na nezavedni ravni, čeprav je ravno v tem tisočletju prišlo do velikih premikov. Po eni strani se je povečal obseg empiričnih sociolingvističnih raziskav, se pravi 
raziskav jezikovnega gradiva, kar sem kot dialektologinja vedno pogrešala, saj nisem mogla primerjati svojih, zvrstno razmeroma ozkih podatkov, z drugimi. Po drugi strani je nastal težko pričakovani govorni korpus, izoblikovali so se začetki slovenskega variantnostnega jezikoslovja, in sicer na sorazmerno sodobni ravni, saj se je takoj začelo tudi povezovanje kvantitativnih pristopov s kvalitativnimi, kar je rezultat osebne pobude Maje Bitenc. Hkrati pa so bile dopolnjene tudi dialektološke raziskave, bodisi s prvinami zaznavne dialektologije, posameznimi raziskavami, ki so se načrtneje posvečale socialni strukturi govorcev, ali z drugačnimi pristopi k dialektološkim raziskavam mestnih govoric.

Vendar vse to poteka precej bolj počasi, kot sem si predstavljala. Naj naštejem nekaj zgledov za to, da omenjena aksioma, po katerih zemljepisna variantnost ni relevantna za raziskovanje sodobnega govorjenega jezika, socialna variantnost pa ne za raziskovanje slovenskih narečij, še vedno delujeta. Na prelomu tisočletja se je to npr. kazalo v tem, da v zbirki Najnovejša zgodovina slovanskih jezikov, ki je izhajala v Opolu na Poljskem v letih 1996-2001, samo v češkem in slovenskem zvezku ni bilo predstavitve zemljepisne razčlenjenosti, kljub temu da je zemljepisna členjenost slovenskega jezika tako rekoč pregovorna. Z dialektološkega vidika na to kaže izločitev področja z neavtohtono poselitvijo oz. t. i. mešanih kočevskih govorov iz dialektoloških raziskav, kot nečesa, s čimer naj se ukvarja sociolingvistika. Anekdotično je to mogoče ponazoriti še z novejšima zgodbama terminološke narave. Andrej Skubic je v svoji monografiji Obrazi jezika (2005) angleški izraz dialect, ki pravzaprav pomeni jezikovno zvrst, zavestno preimenoval v sociolekt in tako spremenil vrednostno razmerje med socialnim in prostorskim. Zadnji terminološki premik je iz leta 2018: v knjigi Mateja Šeklija Tipologija lingvogenez slovanskih jezikov je slovenska dialektologija obravnavana zgolj kot del genetskega jezikoslovja, glavna domena sociolingvističnih raziskav pa je knjižni jezik.

Tako se znajdemo v absurdni situaciji, da je v naših temeljnih narečnih raziskavah narečje pravzaprav obravnavano kot sistem brez govorcev. To je sicer mogoče razumeti kot določen metodološki pristop, ne moremo pa tega razumeti, če celovito opazujemo jezik, ki se govori na nekem določenem področju, ne glede na to, kolikšen jezikovni prostor to opazovanje zajame. S tega vidika je v slovenskem jezikoslovju še vedno vsaj deloma tako, da se sociolingvistika 
ne ukvarja z dialektološkimi izsledki, dialektologija pa ne s sociolingvističnimi, pri čemer zadnja pri svojih osnovnih raziskavah ne uporablja niti tistih osnovnih metodologij in tehnik za analizo govorjenega jezika, ki so v sociolingvistiki dobro razvite. In pri tem izgubita obe vedi. Tudi če se raziskovalni paradigmi sploh ne bi spreminjali, ampak bi samo dopolnili svoje raziskave z izsledki in ugotovitvami druge smeri, bi dobili precej bolj izčiščene in veljavne rezultate. Genetskojezikoslovna raziskava je npr. veliko bolj zanesljiva, če terenski raziskovalec zna določiti socialno vrednost sinhrone variabilnosti obravnavanega gradiva, po drugi strani pa je v slovenskem razdrobljenem narečnem in regionalnem prostoru težko zastaviti sinhrono raziskavo brez dobrega poznavanja bodisi diahronih razvojev bodisi tiste osnovne podlage, na katero se naslojijo druge jezikovne zvrsti.

Rada bi poudarila, da prav zaradi tega - te nezmožnosti, da bi pri se pri nas oblikovala sociodialektologija ali da bi se lotili skupinskih interdisciplinarnih raziskav - ostaja popolnoma neraziskano območje med govorjenim knjižnim jezikom in narečji. Pravzaprav redko koga zares zanima, razen mogoče anekdotično, kaj se dogaja v tem vmesnem prostoru, kakšna je njegova dinamika, kakšna je struktura sprememb, kje so žarišča mestnih govoric, kje prihaja do pojavov, ki niso ne knjižni ne narečni. Zelo si želim, da bi se to v prihodnosti spremenilo. Dober vzorec takšnih raziskav ponuja nemško jezikoslovje. Dolgoročni projekt Rede (Regionalni jeziki v Nemčiji) ${ }^{1}$ je eden največjih trenutno potekajočih jezikoslovnih projektov, trajal bo okoli 19 let, za njegovo izvedbo pa so prejeli okrog 14 milijonov evrov. Projekt strnjuje vse dosedanje izsledke s področij dialektologije, sociolingvistike in variantnostnega jezikoslovja, z množičenjem, s posebnimi anketami pa intenzivno raziskuje sinhrono regionalno nemščino. Gre za portal, ki na enem mestu združuje vse, kar lahko o jeziku poveš prostorskega.

In za konec še malo samokritike. Tudi mi bi morali drugače pogledati na svoje gradivo. Na podlagi starejših jezikovnih podatkov, tudi z uporabo diahronih podatkov za Slovenski lingvistični atlas, in novejših dialektoloških raziskav, ki pri nas v zadnjem času bolj intenzivno potekajo na mikroravni, bi lahko izdelali izhodiščni model za razumevanje regionalne členitve slovenščine, ki bi omogočil izdelavo načrta za nadaljnje raziskave.

1 https://www.regionalsprache.de/ 
Maja Bitenc: Najlepša hvala. K predstavitvi vabim zaslužno profesorico Albino Nećak Lük, ki je delovala na Oddelku za primerjalno in splošno jezikoslovje Filozofske fakultete Univerze v Ljubljani in je utemeljiteljica študija uporabnega jezikoslovja.

Albina Nećak Lük: Pozdravljeni vsi skupaj. Hvala organizatorju za povabilo. Veseli me, da sem dobila priložnost, da skupaj z vami razmišljam o relevantni sociolingvistični tematiki v slovenskem jezikovnem prostoru. Ko omenjam slovenski jezikovni prostor, mislim na celotni etnolingvistični prostor znotraj Slovenije ter na obeh straneh vzdolž njenih meja na območjih jezikovnega stika s sosedskimi jeziki, pa tudi na slovenske jezikovne skupnosti v različnih predelih sveta.

Marsikje berem, da je sociolingvistika mlada veda. To se kot nekakšno mašilo pojavlja v diplomskih, magistrskih, doktorskih delih, pa tudi v tistih nekaj univerzitetnih programih univerz na Slovenskem, ki sociolingvistiko ponujajo študentom, največkrat kot izbirni predmet. Res je, da začetna sociolingvistična raziskovanja sensu strictu postavljamo v 6o. leta prejšnjega stoletja in jih povezujemo predvsem z Labovom in z njegovo znamenito sociolingvistično spremenljivko. Vendar naletimo na poskuse postavljanja proste variacije na raziskovalni repertoar jezikoslovcev že mnogo prej. Lahko bi rekli, da so se zametki sociolingvistike rodili, ko je de Saussure, mojster znanstvenega mišljenja, v stremljenju po čim bolj natančni in jasni opredelitvi ali bolje rečeno zamejitvi predmeta svojega raziskovanja, vzpostavil razlikovanje med pojmom jezika in drugimi, z jezikom povezanimi pojmi. Z uvedbo koncepta parole/ govor, ki de Saussuru pomeni konkretno rabo jezikovnih znakov v natančno določenem kontekstu, se začnejo spreminjati pogledi na možnosti raziskovanja pojava variantnosti v jeziku in jezikih. Tudi med h kategorialnosti usmerjenimi jezikoslovci. Kakor vemo, je variantnost, prosta variacija - torej druga oblika istega s katerekoli ravnine jezikovnega ustroja, kakor jo je opredelil Toporišič; jaz bi dodala druga oblika istega iz bodisi eno-, dvo- ali večjezičnega govornega repertoarja - pred Labovom veljala za nekakšen tabu, za neoprijemljivo, neopredeljivo in s tem nepreverljivo spremenljivko, za problem, ki ga ni mogoče znanstveno opredeliti in empirično preverjati in preveriti.

Ta kratek uvodni ekskurz v zgodovino razvoja sociolingvističnega raziskovanja omenjam prav na današnjem posvetu, ker je ta namenjen nekakšnemu 
pregledu doslejšnjega sociolingvističnega raziskovalnega izplena in urgentnim prihodnjim sociolingvističnim raziskavam. Začetki razvoja sociolingvističnega raziskovanja na Slovenskem se zdijo kot nekakšna replika dogajanja na širši, svetovni sociolingvistični sceni. Razprav o znanstveni relevantnosti sociolingvistike sicer ni bilo veliko, dejstvo pa je, da se stališča, nezaupanje, celo predsodki itd., kakor so jih morali - verjetno povsod - prebroditi začetniki sociolingvističnega raziskovanja $\mathrm{v}$ dokazovanju, da je predmet njihovega raziskovanja znanstveno opredeljiv in preverljiv, pri nas zavlečejo kar tja v 90. leta prejšnjega stoletja in čez. S tem nočem reči, da dotlej v Sloveniji ni bilo sociolingvističnih raziskav. Nasprotno, posamezne sociolingvistične raziskave najdemo na Slovenskem že dobro desetletje po uradni uvrstitvi sociolingvistike med medstrokovne jezikoslovne discipline. Vendar je bilo empirično raziskovanje po pravilu uvrščeno v programe dela različnih raziskovalnih inštitutov, medtem ko ga je bilo bolj malo v raziskovalnih programih univerzitetnih in drugih akademskih ustanov, ki se poklicno ukvarjajo z vprašanji jezika, med njimi tudi ali predvsem slovenskega. Tudi od tod morda zgoraj omenjeno mašilo o mladosti sociolingvistike, čeprav tako rekoč pred našimi očmi nastajajo vedno nove interdisciplinarne povezave pri raziskovanju jezika in soodnosnih pojavov in s tem nove medstrokovne, res mlade jezikoslovne discipline. Sociolingvistika danes med njimi dosega skorajda že častitljivo starost. Ob omenjenih zadržkih do sociolingvistike je treba kot svetel zgled izpostaviti zasl. prof. dr. Bredo Pogorelec, ki je s svojo pedagoško in raziskovalno avtoriteto spodbudila sociolingvistično raziskovanje na območjih jezikovnega stika slovenščine z manjšinskimi oz. sosedskimi jeziki. Tudi njenim spodbudam je namreč treba pripisati dejstvo, da imamo danes na Slovenskem najbogatejšo sociolingvistično raziskovalno bero prav na področju raziskovanja jezikovnega stika, medtem ko se v zadnjih desetletjih po zaslugi njenih študentov, danes univerzitetnih učiteljev, tudi sociolingvistična tematika - da ne rečem problematika - slovenskega osredja in slovenskega jezika prebija na raziskovalni repertoar. Toliko o kratkem oziru v preteklost.

Že samo Sociolingvistično iskrenje, objavljeno v spomin na delo prof. dr. Brede Pogorelec, ki je vir spodbude za današnji posvet, nudi določen, četudi zožen vpogled v aktualno raziskovalno sociolingvistično bero. Zato puščam ob strani drugo vprašanje organizatorjev današnjega posveta: »Kje in kaj se na področju sociolingvistike že dogaja, kako vrednotite to delo? «. Zavzela pa bi se 
za kontinuirano spremljanje in arhiviranje sociolingvistične raziskovalne produkcije. Mogoče bi bilo smiselno za to poskrbeti tudi z uvrščanjem te teme na sezname seminarskih del v nižjih letnikih in bibliografske podatke objavljati v kateri od slovenskih lingvističnih revij. (Morda po vzoru prof. dr. Neldeja, ki je s svojimi sodelavci na ta način oskrbel imeniten vir informacij o evropskih sociolingvističnih študijah in raziskavah $\mathrm{v}$ letnih pregledih $\mathrm{v}$ mednarodni reviji Sociolinguistica.) To bi prispevalo tudi k zmanjševanju večnega problema diseminacije raziskovalnih izsledkov, ki je, kot je opozorila kolegica Grgič, res videti kot gordijski vozel. Ob pisanju različnih strokovnih ocen me dostikrat začudi pomanjkljivo navajanje relevantnih raziskav domačih avtorjev, kar vsiljuje pomisel, da tudi strokovnjaki ne poznamo prav dobro strokovnega izplena svojih kolegov. Potem ni čudno, da naši izsledki, četudi so podani v primerno urejenih poročilih, pač še toliko težje dosežejo ušesa odgovornih za različne družbene odločitve.

Pri razmišljanju o odgovorih na vprašanje »Kaj so glavni aktualni izzivi za slovensko sociolingvistiko? « je treba izhajati iz samega bistva sociolingvistike. Vemo, da sociolingvistika svoj predmet in raziskovalna vprašanja gradi na dejstvu, da se v sporazumevalnem procesu skozi izbiro jezikovnih različic razkrivajo in tudi razkrijejo družbene značilnosti govorca. Na eni strani torej proučuje jezikovne možnosti oz. jezikovna sredstva, ki jih imajo govorci na razpolago pri vzajemni izmenjavi informacij in svojih misli, na drugi pa jo zanima to, kar govorci z izbiro in načinom rabe jezikovnih različic implicitno pripovedujejo o sebi, svoji pripadnosti različnim družbenim skupinam in različnim skupnostim, o svojem dojemanju sogovorcev, njihovih govornih vlog itd. Sociolingvistika je namreč prav to: opazovanje in raziskovanje tega součinkovanja/interakcije oziroma celo sovisnosti med variantnostjo in socialnimi in drugimi pripadnostnimi opredelitvami ter vlogami govorcev. Na eni strani z opazovanjem jezikovne izbire raziskuje implicitna družbena pravila govornega obnašanja, na drugi pa odkriva posledice družbenih razmerij, ki se zrcalijo na spremembah v jezikovnem tkivu.

Seveda lahko slovenski raziskovalci s proučevanjem slovenske sociolingvistične scene, ki je določena v prvi vrsti s slovenskim jezikom, na poseben način prispevajo k razvoju same discipline, torej tudi k novim teoretskim premisam. Gotovo je za vsakega od nas odkrivanje novih smeri razmišljanja o jezikovnih 
pojavih, razvijanje novih konceptov in raziskovalnih prijemov velik, pomemben in vedno aktualen izziv. Vsaj za tiste, ki so z dušo zapisani znanosti. Vendar ima sociolingvistično raziskovanje tudi pomembno aplikativno vlogo - konec koncev sociolingvistika sodi v široko področje uporabnega jezikoslovja, kjer je v ospredju dejstvo, da izsledki medstrokovnega jezikoslovnega raziskovanja širijo razumevanje vloge jezika pri delovanju družbe in oskrbujejo s potrebnim znanjem tiste, ki so odgovorni za z jezikom povezane odločitve oz. za odločitve, ki se nanašajo na jezik.

To spoznanje me vodi do poskusa odgovora na tretje, s prvim tesno povezano vprašanje: »Katere nove oz. dodatne raziskave bi bile najbolj potrebne?«. Repertoar sociolingvističnih tem je obsežen in pester in sivih lis je veliko. In vedno je treba upoštevati avtonomnost raziskovalca. Tega se zavedam in to spoštujem. Prepričana pa sem, da je poleg bolj ali manj solističnih sociolingvističnih raziskav čas za celovito raziskavo jezikovnega stanja v slovenskem jezikovnem prostoru, takšno, ki bi osvetlila smeri jezikovne spremembe in dinamiko družbeno-jezikovnih razmerij. Mislim na kompleksno raziskavo, oprto na teorijo variantnosti, teorijo etnolingvistične vitalnosti, teorijo komunikacijskega prilagajanja, in na še kakšno od relevantnih, tudi novejših teorij ... Mislim na pravo, pristno longitudinalno raziskavo, ki bi zajemala podatke na zajetnih, dobro strukturiranih vzorcih istih govorcev z ustreznimi dopolnitvami, v recimo 3- do 5-letnih panelnih rezih (primer japonske raziskave od sredine 50. let prejšnjega stoletja), s sproti posodobljenim instrumentarijem, ki ga pripravijo strokovnjaki računalniške sociolingvistike (no, ta veda je res mlada), ter z natančno načrtovanimi analizami. Mislim na raziskavo, ki bi prinesla verodostojne posplošitve. To bi morala biti nacionalna raziskava, za katero bi se zavzela država in jo dolgoročno financirala zunaj običajnih ARRS razpisov in bdela nad njenim kontinuiranim dolgoročnim izvajanjem.

Naj na hitro omenim samo najbolj očiten aplikativni izplen takšne raziskave:

1. ogromen jezikovni korpus, uporaben za najrazličnejše nadaljnje jezikoslovne raziskave na različnih strokovnih in medstrokovnih področjih;

2. verodostojni podatki za konsistentno, kontinuirano, dolgoročno načrtovanje jezikovno političnih ukrepov; 
3. verodostojni podatki za nadaljnje jezikovno načrtovanje;

4. verodostojni podatki za preverjanje ustreznosti jezikovno političnih ukrepov

5. itd., itd.

In nenazadnje, takšna raziskava bi odgovorila na zaskrbljenost tistih, ki slovenščini napovedujejo črno prihodnost. Upravičenost te zaskrbljenosti bi bodisi potrdila bodisi ovrgla. Eksaktno.

Seveda bi bilo mogoče takšno raziskavo izvajati samo v tvornem timskem sodelovanju kompetentnih raziskovalcev, $\mathrm{v}$ ciljnem sodelovanju, da ne rečem $\mathrm{v}$ športnem duhu, ne glede na ustanovo, kjer so trenutno zaposleni. Smo pač mali narod z malim jezikom z malo strokovnimi močmi, pa z enako velikimi ali še večjimi potrebami kakor večji narodi in jeziki. Zato je za velike projekte treba združiti moči.

Pozdravljam ta mini sociolingvistični posvet v upanju in z željo, da je to začetek dolgega sodelovanja, če že ne začetek čudovitega prijateljstva, pri raziskovanju jezikovne spremembe ter prepoznavanju zunajjezikovnih, družbenih impulzov, ki do nje pripeljejo.

Hvala za vašo pozornost!

Maja Bitenc: Najlepša hvala. Zdaj pa vabim redno profesorico doktorico Sonjo Novak Lukanovič, predavateljico na Oddelku za primerjalno in splošno jezikoslovje ljubljanske Filozofske fakultete in direktorico Inštituta za narodnostna vprašanja.

Sonja Novak Lukanovič: Spoštovane kolegice in spoštovana kolega. Najprej bi se rada zahvalila organizatorjem, da so se odločili in sklicali takšno srečanje, ki ga osebno ne dojemam kot predavanje o pomenu sociolingvistike oziroma predstavitev sociolingvističnih tem, ki jih vsi dobro poznamo, ampak ga dojemam kot srečanje kolegov oziroma srečanje raziskovalcev, kjer se bomo sestali in začeli z diskusijo, pogovorom o izzivih v sociolingvistiki. Čeprav sem profesorica, torej delam s študenti, pa sem po duši raziskovalka. In tukaj bi se najprej zahvalila svoji mentorici in sodelavki, ki me je vpeljala v čar in svet raziskovanja, profesorici Albini Nećak Lük, s katero sem 
vstopila v raziskovalno področje uporabnega jezikoslovja. Skratka, že pred mnogimi, skoraj 30 leti, smo začeli z raziskavami o etnolingvistični vitalnosti, o problematiki jezika v stiku, o stališčih do jezika. Seveda ne samo v smislu teoretičnega razpravljanja, ampak predvsem z empiričnim pristopom in mislim, da je taka empirija, torej terensko delo, tisto, kar mora biti srčika raziskovanja in mora vedno ostati najpomembnejše v našem sociolingvističnem raziskovanju.

Seveda empirično raziskovanje ni lahko. To zahteva zelo veliko teoretičnega znanja, znanja iz raziskovane tematike, metodološkega znanja, statistike in nenazadnje tudi znanja o okolju in področju, v katerem raziskava poteka. Zelo lahko je narediti vprašalnik, zelo lahko je napisati teoretično delo, zelo težko pa je priti na teren in tam ugotoviti, kaj se dogaja. Zakaj? Predvsem zaradi jezikov v stiku. Vsi vemo, da družbeni, zgodovinski, ekonomski in politični faktorji ustvarjajo ter oblikujejo jezikovno stična območja, kjer pa ima vsak jezik svoj status in položaj. Izbira jezika je vedno odločitev posameznika, toda $\mathrm{v}$ takem okolju je ta odločitev družbeno oziroma politično determinirana in odraža klimo, v kateri posameznik lahko živi v svojem jeziku oziroma ima pravico živeti v svojem jeziku. To sta izhodišči, ki nam zelo natančno pokažeta, kaj se dogaja z jezikom oziroma s posameznikom, ki ta jezik govori. Stična območja bi morali raziskovati, saj na njih živijo in govorijo predstavniki manjšine, večine in tudi drugi. In razlika med jezikom večine in manjšine se v različnih okoljih seveda ne odraža samo v številčnosti, ampak predvsem v obsegu pravic, privilegijev in pa tudi moči. Prav ta odnos med jezikom in močjo je zlasti prisoten v jezikovno stičnih območjih. In ko govorimo o našem področju, mnogokrat pozabljamo, da jezik ni samo sredstvo komunikacije: jezik ima veliko simboliko, ima pa tudi moč. Moč, ki jo mi, sociolingvisti, premalo poudarjamo in izpostavljamo v družbi. Družba se ne zaveda, kakšno vlogo in kakšen pomen ima jezik. In tu se dotaknemo znanosti: ali ni sociolingvistika del znanosti? Čemu je namenjena znanost? Kaj so rezultati našega znanstvenega dela? Rezultati našega dela niso samo objave člankov, predavanja študentom ... rezultate našega dela je mogoče aplicirati tudi na širšo družbo. In nenazadnje bi nas morala politika poslušati in bi morala biti pripravljena izvesti spremembe na področju jezikovne politike, zlasti spremembe, ki se nanašajo na vlogo, položaj in učenje jezika. 
Težko mi je, ko vam govorim, da se družboslovci in humanisti, h katerim sodimo jezikoslovci, pogosto čutimo nekako odrinjeni, ko se v družbi obravnavajo dosežki in pomen znanosti. Pri tem se vedno spomnim misli iz knjige Koristnost nekoristnega, da sta družboslovje in humanistika, kamor sodi tudi jezik, kot plodovna tekočina, v kateri se razvijajo ideje demokracije, enakopravnosti, razvoja. Zato bi morali družbi predstaviti naš pogled na vlogo in moč jezika. Jezik nima samo simbolnega pomena komunikacije, ampak odraža tudi odnose med skupinami, med večino, manjšino in drugimi. In vse to smo mi raziskovali že mnogo let, prav na projektu o medetničnih odnosih v slovenskem etničnem prostoru, ki je bil tako v metodološkem kot v empiričnem pogledu vzorčen - vse je potekalo tako, kot je napisano v teoretičnih delih. In prav v tem projektu se je tudi pokazalo, kako jezik odraža odnose med posameznimi skupinami, predvsem, ali te skupine živijo ena z drugo ali ena mimo druge. Tudi ko obravnavamo manjšinsko tematiko - sem pač raziskovalka na Inštitutu za narodnostna vprašanja, ki se ukvarja z manjšinskimi zadevami, z etnično raznolikostjo, tako v Sloveniji kot tudi v zamejstvu - vedno stremimo k raziskovanju prostora oz. celotnega regionalnega področja. Nikoli se ne usmerjamo samo v raziskovanje manjšinske problematike, ampak širše. Kajti če želimo, da se jezik ohrani, je pomembno, da ga na nekem določenem nivoju sprejema tudi večina. In v tem kontekstu pridemo do raziskovanja stališč do jezika. Seveda se pri obravnavanju jezika v najširšem smislu dotaknemo tudi koncepta enakopravnosti, neenakopravnosti, nediskriminacije, diskriminacije, kajti te tematike so vedno zelo močno povezane z jezikom. Seveda se vsi zavedamo, da so vsa ta okolja ne samo narodnostno mešana okolja, ampak tudi obmejna področja, kjer jeziki predstavljajo tudi neke vrste mejo med kulturami. Tudi o tem še ni bilo dovolj raziskanega.

Ampak vsa ta področja, ki so danes jezikovno stična, mejna področja, niso neki zaprti otoki, ampak so polotoki, ki se jih dotikajo tudi valovi migracijskih tokov in mobilnost prebivalstva, kar seveda vpliva na spremenjeno strukturo prebivalstva, na vzorec življenja in na drugačne oziroma različne jezikovne vzorce, $v$ katerih se spreminja tudi mesto in vloga manjšinskega jezika. Tradicionalno jezikovno-kulturno mešano območje pod takimi pogoji seveda izgublja, spreminja svojo identiteto, ampak izgubljata in spreminjata jo tudi manjšina in avtohtono večinsko prebivalstvo. Skratka, vsi smo podvrženi 
migracijskim tokovom in spremembam. Tudi to je nekaj, kar na nek način še vedno kliče po nadaljnjem, poglobljenem raziskovanju.

Na inštitutu smo skupaj s profesorico Nećak raziskovali tudi že, kaj je dvojezičnost, kaj je večjezičnost. To se pravi, ali večjezičnost danes obstaja na enak način, kot je obstajala pred mnogimi leti. Ali lahko govorimo o medsebojnem vplivu, interakciji večjezičnosti na eni strani in dinamiki transnacionalizma, globalizma, evropeizma na drugi strani? Ena pomembnih posledic te dinamike je seveda tudi velika sprememba funkcij in položajev različnih jezikov v primerjavi enega z drugim oziroma jezikov v stiku, kar se odraža tako na nacionalni, regionalni kot na globalni ravni in zaznamuje nacionalne jezikovne politike in jezikovne prakse $\mathrm{v}$ takih okoljih.

Seveda se raziskovalno na inštitutu ukvarjamo tudi z našimi narodnostno mešanimi območji, v katerih se izvaja institucionalna dvojezičnost. Ugotavljamo uspešnost take institucionalne dvojezičnosti: kot je že povedal nekdo pred mano, imamo izredno izdelan, tako rekoč edinstven pravni sistem, v realnem življenju, v praksi, pa je mnogokrat drugače. In kaj so vzroki za to? Ali so instrumenti jezikovne politike ustrezni ali neustrezni? Pri tem se dotaknemo tudi ekonomskega vidika: država zagotavlja dodatek za dvojezičnost, finančno jo nagrajuje že od poznih 50. let prejšnjega stoletja. Preseneča nas, da so se takrat, v času socializma, odločili finančno nagraditi nekoga, ki govori dva jezika, se pravi lahko uporablja še italijanščino ali pa madžarščino. Zakaj je bilo to uvedeno, je seveda predmet širšega raziskovanja. Ampak vse to raziskujemo in ugotavljamo povezave z jezikovno politiko. $Z$ raziskovanjem etnolingvistične vitalnosti, jezikovnega prilagajanja, družbenih procesov jezikovnega stika pridemo tudi do ekonomskega vidika jezika, do katerega so nas na inštitutu privedle predhodne raziskave. Nismo ga začeli raziskovati, ker bi v neki teoriji prebrali, da je ekonomski vidik pomemben: naše predhodne raziskave, raziskave v 9o. letih prejšnjega stoletja, so nam nakazale močno povezavo ekonomskega vidika z rabo jezika. Mobilnost, medgeneracijski stiki, mešani zakoni - vse to so tematike, ki bi jih lahko še poglobljeno raziskovali.

Druga tematika, ki jo v raziskovanju moram omeniti, so Romi in romski jezik. Trenutno na inštitutu poteka pilotni projekt poučevanja romščine, kjer s pomočjo dodatnega pouka romščine za romske otroke spremljamo napredek njihovega opolnomočenja in posledično boljše jezikovne kompetence, tako v 
romščini kot v slovenščini. $Z$ enakimi cilji in namenom smo se lotili večletnega eksperimentalnega projekta uvajanja novih večjezičnih pedagoških pristopov s poudarkom na romščini. Večjezičnost je torej nova realnost in skupni imenovalec vseh raziskovalnih udejstvovanj, ki bi jih bilo treba zastaviti čim širše in multidisciplinarno. Skratka, tudi to je eden od sociolingvističnih izzivov.

Tematik za raziskovanje je tako zelo veliko. Kar bi želela poudariti in kar osebno čutim, da nam primanjkuje, je prav povezanost nas vseh. Kajti projekte izvajamo nekako parcialno in koristno bi bilo, da bi skupaj zastavili longitudinalne projekte, kajti prav longitudinalni projekti so tisti, ki odpirajo nova vprašanja in dajejo nove odgovore. Kako prepričati državo, družbo, da je jezik pomemben? Politika je za nas to, kar je za nek tehnološki inštitut gospodarstvo. Tehnološka znanost tudi ustvarja inovacije, nove produkte, ki pa ne pridejo vsi vedno v tovarno, da bodo izdelani. Tako mora tudi družba ustvarjati nove poglede, modele, opozarjati na probleme, kajti jezik je pomemben indikator identitete, ki lahko vodi v diskriminacijo, nespoštovanje, to pa je lahko vzrok nestabilnih razmer, lahko vodi v konfliktne situacije, toda o tem nikoli ne govorimo. Ni raziskav, ki bi ugotavljale, ali je jezikovni stik v Sloveniji jezikovni konflikt. Želim si, da bi nekako prišli do politike, ki nas bo poslušala in ki nam bo omogočala longitudinalno raziskovanje, katerega namen ni, da o rezultatih predavamo študentom ali objavimo članek, ampak predvsem to, da se izboljša družba v vseh pogledih. Hvala organizatorju.

Maja Bitenc: Najlepša hvala. Naslednji govornik je doktor Krištof Savski, ki je diplomiral na tukajšnjem Oddelku za prevajalstvo, magistriral in doktoriral v Veliki Britaniji pri znameniti profesorici Ruth Wodak, sedaj pa poučuje na Tajskem, na Prince of Songkla University in je z nami na daljavo.

Krištof Savski: Vsem lep pozdrav in hvala lepa za povabilo. Kot je povedala Maja, sem podiplomski študij opravil v Veliki Britaniji, po sicer zelo lepem študiju na Filofaksu, na Oddelku za prevajalstvo, zdaj pa že peto leto delam na Tajskem. Ravno te dni mineva 10 let, odkar sem se prvič odpravil iz Slovenije, tako da bom danes razmišljal o slovenski sociolingvistiki bolj od zunaj. V doktoratu sem se sicer ukvarjal s slovensko jezikovno politiko, od takrat naprej pa večinoma pišem bolj o sociolingvističnih vprašanjih angleščine in drugih jezikov v jugovzhodni Aziji, predvsem seveda na Tajskem. Torej bom morda predstavil nekoliko drugačen pogled, a upam, da bo zato toliko bolj 
zanimiv. Res pa hvala za organizacijo tega zelo zanimivega in zelo dobrodošlega dogodka.

Za začetek bi se vprašal, kaj je sociolingvistika. Seveda bi lahko preprosto rekli, da je sociolingvistka veda o razmerjih med jezikom in družbo, vendar pa smo danes videli, da je to vseeno treba veliko natančneje definirati. Iz vseh prispevkov je jasno videti, da je to zelo empirična veda: če po objavah, knjigah in konferencah ocenimo, kaj sociolingvistika je, vidimo, da je to večinoma veda, usmerjena k empiričnemu preučevanju realnosti jezikovne rabe. Sociolingvistika ima danes izjemno robusten nabor kvantitativnih in kvalitativnih raziskovalnih metod, od jezikoslovnih v ožjem smislu, torej fonetike, fonologije, sintakse in drugih, do veliko bolj socioloških in antropoloških metodologij, kot recimo analiza diskurza in etnografija, ki sta moji specialiteti - jaz sem, za razliko od večine drugih govorcev tukaj, stoodstotno kvalitativni raziskovalec. Kot je ravno pred menoj povedala Sonja Novak Lukanovič, je sociolingvistika tudi kritična veda, torej takšna, ki ne razmišlja samo o jeziku in se samo posredno dotika razmerij moči, ampak ta razmerja tudi neposredno preiskuje in o jeziku razmišlja v luči njegove vloge v razmerjih neenake moči v družbi.

Najbolj bi se osredotočil na tretjo karakteristiko današnje sociolingvistike, namreč njeno usmeritev k dinamiki v smislu, da se vedno bolj zaveda, da so statične definicije jezika in jezikov ter družbe in družb problematične. S tem mislim na strukturalistično pojmovanje jezika kot sistema s pravili in sredstvi, ki je bilo brez dvoma dominantno v 20. stoletju, tudi v sociolingvistiki, in je še danes izjemno pomembno. Variantostna sociolingvistika, ki jo je definiral William Labov in se sedaj razvija v svoj tretji oziroma morda celo četrti val, je še vedno vezana na to sistemsko pojmovanje jezika, s tem da poskuša ta sistem statistično navezovati na družbene spremenljivke, kot so prostor, spol, starost, socioekonomski razred in druge. Danes je ta sociolingvistika brez dvoma še naprej aktualna, a se hkrati pojavlja vedno več vprašanj o smiselnosti takšnega dela, zlasti spričo študij interakcije v diskurzu, ki kažejo, da se jezikovna sredstva opomenjajo kot del družbenih dejanj, torej da so umeščena v kontekst rabe; o tem na primer govori Ron Scollon, zdaj že preminuli ameriški sociolingvist. $\mathrm{V}$ bolj diskurzivno usmerjeni sociolingvistiki se problematizira rigidna navezava določene jezikovne varietete na neko vrsto družbene identitete: če si od tukaj, govoriš tako; če si ženska, govoriš tako; 
če si heteroseksualec, govoriš tako. Naj poudarim, da se tako razmišljanje ne kaže vedno kot popolnoma napačno, pač pa se poskuša bolje upoštevati kompleksno realnost vseh družb.

To vprašanje razmerja med jezikovnim sredstvom in družbenim pomenom (indeksikalnost) ima že dolgo zgodovino. Vsestranski ruski literarni teoretik Mihail Mihajlovič Bahtin je v prvi polovici 20. stoletja pisal o večglasnosti in večideološkosti diskurza in jezika, torej o heteroglosiji in polifoniji. Po Bahtinu ideološki pomen nekega jezikovnega sredstva (čemur Silverstein reče »popolno jezikoslovno dejstvo « oziroma v angleščini total linguistic fact) ni enodimenzionalen, pač pa je vpet v raznolik diskurz in se ga lahko mobilizira z več ideoloških vidikov. Tovrstno večdimenzionalnost sistemska definicija jezika zelo težko zajame, kar lepo pokaže primer razprave o rabi slovničnega spola na Filofaksu, ki jo je omenila že kolegica Monika. V tej razpravi je bil z dela slovenistične stroke podan sistemski argument, da slovenščina preprosto že ima jezikovno sredstvo za izražanje spolne nevtralnosti, to je moški slovnični spol, in da predlagani ukrep fakultete (da naj se v uradnih besedilih uporablja nevtralni ženski slovnični spol) zaradi tega ni sprejemljiv, saj naj bi posegal v nespremenljive notranje zakonitosti jezika. Tak sistemski argument preprosto ne zmore zajeti dejstva, da se očitno v diskurzu to sredstvo, torej slovnični spol, opomenja z več ideoloških zornih kotov, da za neke uporabnike pomeni nekaj, za druge pa ima drugo ideološko razsežnost. Tudi zato v zelo specifičnem kontekstu rabe jezika (uradna besedila na FF) premik od rabe enega sredstva k drugemu ne more pomeniti posega v statičen jezikovni sistem, pač pa je del naravne geneze diskurza oziroma razvoja rabe jezika v družbi. Vse to nam pove, da jezik s sociolingvističnega vidika ni enodimenzionalen in ni statičen. Hkrati s sociolingvističnega vidika jezik tudi ni avtonomen oz. ločen od drugih ravni tvorjenja pomena, saj je na voljo veliko raziskav, v katerih se jezikovna raba obravnava kot del raznolikega nabora semiotičnih sredstev, ki so na voljo članom neke dane družbe. Lep primer je delo o pisni rabi jezika v javnih prostorih, po slovensko jezikovna krajina (angleško linguistic landscape), kjer se raziskuje skupno opomenjanje jezikovnih in drugih vizualnih sredstev, na primer rabe barv, umeščanja elementov v prostor, velikosti in tako dalje.

Še ena pomembna točka je, da je sodobna sociolingvistika veda, ki raznolikost in večjezičnost - zdaj se v evropskem kontekstu govori o raznojezičnosti 
(angleško plurilingualism) - pojmuje kot naravno stanje v vseh družbah, ne pa kot izjemo. Vedno več se nasploh razmišlja o tem, da sama ideja poimenovanih jezikov - na primer slovenščine, hrvaščine, italijanščine - in varietet na primer knjižni jezik ali pogovorni jezik - ni nevtralna, ni samo znanstveno določena, pač pa je produkt ideologije in služi interesom moči. Torej vprašanja, kaj je slovenščina, kaj je dobra oziroma prava slovenščina, niso nevtralna, niso neko naravno dejstvo, ki ga sociolingvistika opiše, pač pa so družbeno konstruirana in odsevajo ideologije, kot je recimo nacionalizem in elitizem. To je zelo relevantno predvsem pri manjšinskih govorcih, ki jih je omenjala že Matejka Grgič, saj pri njih ta tradicionalni model nacionalne države, polne enojezičnih govorcev, ne deluje, posledica tega pa je, da je njihova raznojezičnost pogosto marginalizirana, ko pride do izobraževalnih kontekstov. Tukaj se je sicer potrebno vprašati, ali nismo vsi raznojezični na različne načine, saj nihče od nas ne govori in piše vedno na enak način. V tej smeri se zdaj v sociolingvistiki veliko razmišlja ne samo o odmikanju od sistemskega razumevanja jezikov, pač pa tudi o odmiku od same ideje jezikov kot zamejenih sistemov, ki so ločeni od kontekstov rabe ter tudi od uporabnikov. Namreč, kot je omenila Karmen Kenda-Jež, pri sistemskem pojmovanju se hitro zapade v obravnavanje jezikov oziroma varietet kot »sistemov brez uporabnikov«, torej kot nečesa, kar posamezniki samo pasivno realizirajo, ne da bi imeli možnost v ta sistem posegati, ga definirati. Tu s sociološkega vidika govorimo o vprašanju, kje je jezik v razmerju med strukturo in agentnostjo. O tem razmišlja na primer zelo sodobna literatura okoli koncepta translanguaging (morda bi lahko slovenili kot »čezjezičenje«), ki je poskus konceptualizacije rabe jezikovnih sredstev kot dinamičnega procesa, ki je vpet v zelo specifične družbene okoliščine in kontekste in kjer zgodovinske, politične meje poimenovanih jezikov ne štejejo vedno absolutno, tako kot to določajo ideologije nacionalne države.

Mislim, da sociolingvistiki slovenščine ta razvoj vede, ki ga jaz tu zelo površinsko povzemam, postavlja nekaj specifičnih izzivov. Glavni izziv za mene kot raziskovalca je nujen odmik od ideologije nacionalnega standardnega jezika in nanjo vezane tradicije predpisovanja, ki danes slovenistiko še naprej definira. Tukaj je, kot so povedale govorke pred mano, treba predvsem kultivirati znanstveno kulturo, ki se avtentične, prave jezikovne rabe ne boji, ampak jo zanima, ne glede na standardno oziroma nestandardno rabo in ne glede na 
osebne jezikovne sodbe ali znanstvene predpostavke. Potrebno je spoznanje, da v vsakem kontekstu jezikovne rabe dihotomija standardno/nestandardno (oziroma po domače prav/narobe) ni relevantna. Tam, kjer pa je relevantna, pa tudi ni statična, pač pa je pomensko umeščena v kontekst, z njo pa se torej ta prostor med knjižnim in pogovornim jezikom, ki ga je omenila Karmen Kenda-Jež, tudi premika. Treba je tudi spoznati, da dihotomija standardno/ nestandardno ni samo dinamična, ampak je tudi vpeta $v$ razmerja družbene neenakosti in je zato ne moremo obravnavati kot nevtralno znanstveno dognanje, pač pa jo je treba obravnavati kritično. To tudi pomeni, da je potrebno relativizirati znanstveno vedenje o jeziku in razumeti, da so jezikoslovci sami tudi del govorne skupnosti ter da njihova spoznanja odsevajo družbene razmere. Nadalje je treba več razmišljati o tem, da je slovenska jezikovna skupnost izjemno raznolika, raznojezična in vpeta v procese kulturne in jezikovne izmenjave, ki jih ne moremo opisati zgolj glede na pripadnost nacionalnim skupinam ali jezikom. Angleščine na primer ne moremo obravnavati preprosto kot vpliv »anglo-saksonske« kulture na slovensko, saj so lahko angleški jezikovni elementi nosilci mnogih različnih kulturnih pomenov, tudi slovenskih.

Za zaključek, predvsem je treba spoznati, da slovenščina ni ena sama, ampak da slovenščine so, da vse obstajajo v rabi, da se vse spreminjajo in prepletajo ter, na koncu, da so vse vredne enakovredne, ozaveščene sociolingvistične analize. Hvala lepa.

Maja Bitenc: Najlepša hvala! In za konec še redni profesor Marko Stabej z Oddelka za slovenistiko Filozofske fakultete, tudi predsednik Centra za slovenščino kot drugi in tuji jezik.

Marko Stabej: Lep pozdrav. Jaz bom tako rekel: ni čudno, da je Krištof s takimi in tako izraženimi stališči našel službo na Tajskem, ker je tam dovolj daleč, da se zdijo nenevarna. Pravzaprav bi najraje kar obmolknil, ampak čisto ne bom. Samo nekaj opomb.

Jaz sem pritaval v sociolingvistiko iz stilistke, ker nisem mogel razumeti, kako je v 19. stoletju lahko veljalo za kvalitetno literarno delo nekaj, kar je sodobnemu bralcu popolnoma nezanimivo, in ni bilo drugačne možnosti, kot to gledati kontekstualno. Ena od osrednjih pomanjkljivosti slovenskega jezikoslovnega prostora je to, da je $\mathrm{v}$ resnici jezikoslovje sluga $\mathrm{v}$ rokah ideologije, in to ne 
nujno strankarske ideologije, ampak globoke ideologije nacionalnega, in da ima, čim hoče izstopiti iz tega, hude težave, saj se sicer zdi popolnoma nepotrebno. In ne gre samo za razmerje družba - jezik, tovrstno prepletanje in součinkovanje, ampak tudi na splošno, s kontekstom. Slovensko jezikoslovje, vsaj v mainstreamu, je še vedno pretežno dekontekstualizirano oziroma si konteksta jemlje samo toliko, kolikor ga nujno rabi, da lahko ohranja videz nujne potrebnosti za nadaljnje življenje neke nacionalne in državne skupnosti, ki je domnevno trdna in od nekdaj je in vedno bo. Pa čeprav vsi vemo, da se spreminja, ampak marsikdo noče niti pomisliti, da bi to spreminjanje sprejel, kaj šele, da bi ga resnično raziskoval. Zato je sociolingvistika, kot je bilo tu malo nakazano, v slovenskem prostoru pravzaprav slabšalna oznaka, če že ne zmerljivka. Deloma tudi upravičeno: kot smo že večkrat slišali, je sociolingvistika težko področje za kvalitetno raziskovanje. To kaže tudi primer omenjene štiri leta stare raziskave, ki je bila ultra pomanjkljiva, v marsičem tudi zavajajoča, v zvezi z njo pa je bil problematičen tudi marketing. Kar je morda najhujše: če misliš, da dobiš rezultate, pa sploh ne veš, kaj imaš. In v tem smislu je najbrž tudi ideja kolegice Albine Nećak Lük, da šele longitudinalno raziskovanje prinese zanesljive rezultate, čeprav je ob spremenljivosti situacije ta longitudinalnost in njena zasnovanost najbrž zelo težek izziv. A sam mislim, da je ravno $\mathrm{v}$ ta izziv treba ugrizniti in po mojem je predlog, da enkrat poskusimo prijaviti nek skupni projekt, vsaj neke parametre, dober. To bi bil nek korak. Ker sicer samo govorimo, kako bi bilo lepo, da se povezujemo, v resnici pa vsak hoče samo preživeti sebe in svojo institucijo. In to je tudi težava slovenskega prostora, zato ker nenehno govorimo, kako bi bilo dobro, v resnici pa se sodeluje tako rekoč nič, še znotraj oddelkov na fakultetni ravni ne, kaj šele na medinstitucionalni.

Jaz bi rekel, da imamo dve možnosti. Če bi bili kritično in znanstveno uspešni, smo prave zgage v slovenskem prostoru, saj bi zamajali vse, kar se zdi vsem, od levih pa do najbolj desnih politikov, samoumevno. »Jezik je identiteta, brez knjižne slovenščine ni naroda « in tako naprej, mi pa začnemo nekaj šumeti, nato pa uspemo mogoče celo dokazati, da to sploh ne drži. Nihče ne potrebuje tega. Oziroma jaz mislim, da vsi potrebujemo to refleksijo, ampak zato bi rekel, je težava biti sociolingvist, ker je težko empirično raziskovati in potem to modelirati in nekako komunicirati, čeprav se strinjam s kolegico Matejko, da 
so šele takrat aplikativne rešitve zares možne. Ker če načrtuješ nekaj, kar je nerealno in neizvedljivo, lahko načrtuješ nov projekt, pa še en nov projekt, pa tega nikoli ne boš mogel uresničiti. In takšnih projektov imamo tu vse polno, recimo iskanje idealnega govorca za normiranje govorne slovenščine za naslednjih 30 let. Takšnega idealnega govorca, kot smo tukaj skoraj vsi prepričani, ni in ga nikoli ne bo. In še vedno se ga išče. Ne samo šest oseb, ampak cela stroka išče tega govorca.

Če pa sociolingvisti in sociolingvistke nismo kritični in uspešni, smo pa tako ali drugače samo v službi te ali one ideologije. Da malo še z druge strani govorimo o statusu, o jezikovni krajini, o takšnih in drugačnih zadevah, a pravzaprav samo ozaljšamo neko že obstoječo ideologijo. In dober primer tega je recimo nesorazmerje v novi resoluciji o nacionalnem programu jezikovne politike, kjer uvodno poglavje o jezikovni krajini govori o jezikovni lojalnosti, torej da jo je treba razvijati. Nič se pa ne vpraša, kateri lojalnosti, čigavi, do katerega jezika, do vseh jezikov ali samo do avtohtonih. Izgleda pa zelo sociolingvistično, na prvi pogled. To je takšno prekletstvo.

Če smo humanisti - in jaz mislim, da smo - ne smemo samo govoriti, kaj vse jezik je, ampak moramo pravzaprav razumeti, s tem da raziskujemo - ne nekaj, kar je pomembno za slovensko državo ali slovenski narod ali slovenski jezik, ampak nekaj, kar je pomembno za človeškost. Ampak to je pedagoško in raziskovalno težko. Ne samo glede tega, da je zahtevno narediti raziskovalni projekt s terenskimi raziskavami, z modeliranjem in tako naprej. Težko je tudi učiti, težko je mentorirati diplome, če študenti niso pripravljeni prebrati niti dveh do treh knjig. Če lahko v bolj hardcore jezikoslovju nekaj precej hitro razvrstiš, umestiš in imaš potem občutek, da si nekaj novega dodal veliki stavbi slovenskega sistema, čeprav ne veš, koliko slovenščin je, kakšne so, kako jih dojemamo. Tukaj se mi zdi nekakšna groza početi nekaj, kar bo destabiliziralo splošno predstavo o jeziku, in zato tudi tega ne moremo skomunicirati. Ker imamo v bistvu premalo podatkov in vedenja, hkrati pa tudi okolje ni naklonjeno temu, da bi razvili nek narativ, kjer bi različnost in jezikovno ranljivost začeli obravnavati kot normalno od vrtca naprej. Ampak se nenehno perpetuirajo ideološka vprašanja, kaj je potrebno, kaj ne ... Ni čudno, da se potem pojavljajo takšne metafore: predstojnik Inštituta za slovenski jezik je imel v Mladini intervju in je javno izjavil, da jezikoslovci nismo več psi čuvaji, ampak 
smo psi vodniki. Jaz se ne počutim kot pes vodnik. Pes vodnik koga? Ali so govorci slepi? V tem smislu obstaja neka dominantnost znanstvenega jezikoslovja, ki ga lahko primerjamo s tem, da bi nam dobri mehaniki ali pa celo fiziki urejali prometno situacijo, prometno infrastrukturo. To ne gre. Tisti, ki nam je do tega, ki nas to zanima, moramo to zanimanje združiti, napisati en skupni, večji projekt. Seveda z njim ne bomo vsega rešili, bi pa tukaj lahko bi en konkreten korak. Hvala lepa.

\section{RAZPRAVA}

Maja Bitenc: Nadaljujemo torej z razpravo. Marko, ti si odločno rekel, da bi pripravili projekt, potem upali na dolgotrajno financiranje in longitudinalno raziskavo, obširno in celovito in polno stvari obsegajočo, ampak se mi zdi, da smo vseeno govorili o zelo različnih stvareh. Eno bi bil projekt v smislu spremljanja avtentične jezikovne rabe in jezikovnih stališč. Potem, kar je izpostavila Monika, bi morali raziskovati širše družbeno zelo relevantne teme, kot je slovenščina v šoli, jezik in razne ideologije. Ali ima to dvoje nek skupni imenovalec oziroma kako bi bilo lahko prvo mogoče uporabno za drugo oziroma ali so to povsem ločene stvari in ločeni projekti? Glede sklopa o jeziku in šoli se zastavlja vprašanje, kje začeti. Meni se zdi pomenljivo, ko otrok sprašuje, zakaj se nekaj uči. Ali ko maturanti tarnajo, da znajo vse mogoče stvari, niso pa pismeni, se ne čutijo suverene pri rabi slovenščine. Kaj je smiselno v šoli početi in kako je to povezano s študijem slovenščine in vlogo jezikoslovja, stanjem duha v jezikoslovju, kot si ga zelo dobro opisal? Ne vem, ali imamo pri vseh teh idejah res nekaj, za kar bi rekli: »To bi bilo potrebno najprej.« Ali oziroma koliko in kako so te različne pobude združljive in povezane med sabo?

Nataša Gliha Komac: Jaz bi se tu oglasila. Naša raziskava pred štirimi leti je imela vrsto pomanjkljivosti, a smo se iz nje tudi marsikaj naučili. Zdi se mi povezano s tvojim vprašanjem, zlasti zaradi tega, ker smo se mi takrat lotili resnično velike in kompleksne raziskave, $v$ katero so bili in smo bili vključeni raziskovalci in strokovnjaki z zelo različnih ustanov, zraven pa smo poskušali vključiti tudi jezikovne uporabnike, tako predstavnike različnih raziskovalnih, izobraževalnih in strokovnih ustanov in služb kot čisto konkretne jezikovne uporabnike, specializirane in splošne. Kot je bilo prej izpostavljeno, so se porajala zelo različna vprašanja in soočili smo se s težavo, kako naenkrat, v eni 
raziskavi, pokriti različna področja in različna vprašanja ter hkrati priti do celostnega vpogleda. Raziskava je potekala tako kratek čas, da je bilo to skoraj nemogoče, a ta izkušnja je vsakemu posebej dala kar nekaj spoznanj, vzpostavila se je mreža raziskovalcev in mislim, da smo si takrat zastavili številna vprašanja, ki se zdaj skozi čas razvijajo naprej in dobivajo odgovore oz. nova vprašanja. Preizkušen je bil kompleksen metodološki aparat in zelo različne tehnike zbiranja podatkov. Tako da jaz na to, da je imela ta raziskava samo pomanjkljivosti, nikakor ne bi pristala, hkrati bi pa še opozorila, da je bila ta raziskava zelo večplastna. Najprej smo se po delovnih skupinah dobivali poznavalci zelo različnih področij, se pogovarjali o problematikah, soočali zelo različna mnenja in vprašanja. Drugo je bila izvedba spletne ankete ter nato iskanje povzemalnih odgovorov. Ob tem je bilo opravljenih še več manjših, izrazito ciljno naravnanih raziskav, npr. med uporabniki slovenskega znakovnega jezika, med uporabniki z motnjo v duševnem razvoju, anketna raziskava med načelniki vseh 58 slovenskih upravnih enot in še kaj bi se našlo. Gradivo še čaka na obdelavo, saj je bil to ciljni projekt in je bilo treba priti do rezultatov in smernic v zelo kratkem času, ki smo jih zato zaradi hude časovne stiske vlekli dobesedno iz rokava, pri čemer pa so se o posameznem področju vedno odločali strokovnjaki, poznavalci področja, in sicer tako na osnovi specializiranih znanj in izkušenj kot tudi na konkretnih rezultatih in spoznanjih opravljenega raziskovalnega dela. To je bil zelo zahteven in kompleksen poskus celostne raziskave, kjer smo se vsi naučili, da takšna raziskava potegne za sabo garanje in zelo veliko različnih znanj in združevanje zelo različnih področij. Kar pa je vse prej kot enostavno. In to je nesporno konkreten primer empirične izkušnje in poskusa sodelovanja in raziskovanja celotnega slovenskega jezikovnega prostora, za katerega mislim, da je bil tudi uspešen. Sicer pa sem res vesela današnjega srečanja, saj so izmenjave mnenj, pogledov, tudi zgolj »slišanje« danes povedanega dragoceni za vse nas, ki se tako ali drugače ukvarjamo z jezikoslovjem.

Albina Nećak Lük: Zelo se strinjam z vsemi, ki so opozorili na dinamično naravo družbe in na jezikovne posledice te dinamike. Vendar mislim, da to ni zadržek za skupno raziskavo, ki bi pokazala, kakšno je pravzaprav stanje v posameznih panelnih rezih; to bo namreč pokazalo tudi jezikovne posledice družbene dinamike. V prispevku sem navedla nekaj tradicionalnih teoretskih konceptov, omenila pa sem še, da so na razpolago tudi drugi: to je stvar 
načrtovanja takšne raziskave. Pomembno je, ali obstaja volja, želja prepoznati stanje, ugotoviti, kakšni procesi potekajo v družbeni komunikaciji, kaj se ob tem dogaja $\mathrm{z}$ jezikom in kaj pravzaprav to dogajanje pomeni za prihodnost te dinamične, razvijajoče se skupnosti. Ampak če se odpovemo spremljanju tega razvoja, tega spreminjanja, potem smo se odpovedali tudi eksaktnemu pogledu na jezikovno stanje, na jezikovna razmerja in dinamiko ter s tem na jezikovno spremembo. Zakaj toliko poudarjam eksaktnost? Nekajkrat ste omenili reševanje. Jaz ne govorim o reševanju. Kaj bomo reševali? Mi smo znanstveniki, mi moramo stvari prepoznavati, ugotavljati, ali stvarnost neke predpostavke, ki jih preverjamo, potrjuje ali ne. Rešujejo naj drugi ob upoštevanju izsledkov naših raziskav, mi moramo dati odločujočim v politiki, tudi jezikovni, verodostojno preverjene podatke o stanju, trenutnem, prihodnjem. Ta ambicija nekaj reševati me rahlo moti, ker je to naloga nekoga drugega. Res pa je, da morajo biti rezultati naših raziskav verodostojni, vedno znova preverljivi in omogočati morajo posplošitve. Povrh tega je treba podatke in izsledke pripraviti tako, da bodo berljivi tudi za tiste, ki so odgovorni tako za družbeno spremembo kakor tudi jezikovno spremembo znotraj nje. In še nekaj: Ker se zavzemam za longitudinalni projekt, moram poudariti še, da je za dober raziskovalni projekt potrebno tudi financiranje načrtovanja projekta. To se mi zdi bistveno. Projekt, ki naj bi bil longitudinalen, sploh dolgoročen in bi segal v neko neznano prihodnost, za katero upam, da jo boste doživeli, je treba pripraviti z vidika današnjega znanja in s predvidevanjem o vključevanju novih konceptov. Bistvena značilnost longitudinalne raziskave je namreč tudi to, da vključuje znanja in spoznanja, ki nastajajo med samim raziskovanjem. To pa ni majhno delo, zato je treba že v predpripravah predvideti čas in denar za načrtovanje projekta.

Marko Stabej: Albina, tudi ta tvoja misel o pregledu sociolingvističnih ugotovitev v revijah ...

Albina Nećak Lük: Predlagala sem, da se kakšna jezikoslovna revija posveti tudi temu, da recimo vključi letni pregled domače sociolingvistične raziskovalne produkcije. Takšni pregledi bi bili koristni tudi za katerokoli drugo strokovno področje.

Marko Stabej: Ja, samo nekako nihče tega ne dela več. Mogoče moramo vzpostaviti nek forum, kjer bi lahko to tudi nekako pisno oblikovali, mogoče 
tudi moderirali ... Dobro, saj bo ta razprava tudi zapisana, ampak če bi še malo naprej razmišljali. Seveda ne more biti vse v eni raziskavi, to je gotovo, da ne. Jaz nisem želel biti kritičen, da nič ni dobrega, seveda je bilo narejenega ogromno dela. Ampak, to je približno tako, kot če bi s sredstvi za hišo želel zgraditi stolpnico, ker ne moremo zanikati, da tu ni bilo nekega namena ustvarjati največje, najboljše in tako naprej. Skratka, po mojem nek forum ali pa mogoče načrtujemo in poskušamo dobiti posebno tematsko, sociolingvistično številko, ker, roko na srce, najbolj reprezentativna Slavistična revija ima bolj malo sociolingvistike, milo rečeno, in najbrž so tudi neki razlogi za to. Je pa več možnosti, da bi mogoče do česa takšnega prišli kje drugje, da bi na kakšen tak način poskušali naprej razvijati.

Albina Nećak Lük: To ni ključno, to je bil pač eden od mojih predlogov. Jaz se niti ne bi zavzemala za to, da se naredi kakšna posebna revija. Društvo za uporabno jezikoslovje je nekaj časa izdajalo revijo Uporabno jezikoslovje, ampak zdaj to spi. Če bi se kdo potrudil, bi tudi Uporabno jezikoslovje lahko opravljalo tudi takšno funkcijo. Razumem, da je to zelo, zelo težko. Če za tem ne stoji institucija in je treba računati na to prostovoljno delo, potem je brez izrazite notranje motivacije, kot pravi Sv. Avguštin, težko izvesti kakršenkoli projekt. Časi prostovoljstva so, kot je videti, minili. Na internetu je danes res marsikaj dosegljivo. Vseeno pa ne bi bilo odveč k pripravam takšnih pregledov pritegniti študente v okviru seminarjev ali kako drugače.

Nataša Gliha Komac: Mislim, da je imela profesorica v mislih mednarodno sociolingvistično revijo Sociolinguistica, kjer vsako leto ena institucija v posamezni državi poroča o temeljnih objavah, delih s področja sociolingvistike. Pri nas, kolikor vem, je nekaj časa za to skrbel Inštitut za narodnostna vprašanja.

Monika Kalin Golob: Mogoče bi predlagali uredništvu, da se ena tematska številka Slavistične revije na to temo naredi.

Tina Lengar Verovnik: Jaz nisem sociolingvistka, sociolingvistiko samo spremljam, že odkar me je profesorica Albina Nećak Lük navduševala med študijem splošnega jezikoslovja, to je zdaj že skoraj 30 let. Ampak zelo všeč mi je zamisel o nekem repozitoriju sociolingvističnih člankov, raziskav, zato ker sem vedno znova navdušena nad tem, kaj vse v našem prostoru nastaja, kaj vse najdem, ko usmerjeno iščem za potrebe svojega predvsem pedagoškega 
dela, včasih tudi raziskovalnega, ko kaj sežem proti sociolingvistiki. Res bi bilo za vse nas, ki se manj razgledujemo po tem področju, ki ga manj sproti spremljamo, koristno, če bi imeli na enem mestu zbrano vse za zadnjih mogoče 20 let, ko je to področje veliko bolj živo, ko nastajajo raziskave tudi v okviru doktorskih in magistrskih del, kakovostne stvari, zanimive stvari, ki jih je vredno brati, če seveda veš, da obstajajo.

Marko Stabej: V tem smislu je bila zasnovana knjiga Sociolingvistično iskrenje, ki pa seveda ni niti približno pokrila vse produkcije, ampak tisto, kar je bilo mogoče na ta način, $v$ tem času.

Krištof Savski: Lahko še jaz tukaj nekaj dodam? Mislim, da je iskanje prostora za sociolingvistično razpravljanje in razmišljanje vsekakor potrebno. Še zdaj smo namreč vsi kar nekako veseli, da lahko končno govorimo o sociolingvistiki, kakor da je to neka marginalna stvar, o kateri bog ne daj, da bi se preveč odprto razpravljalo. To je na slovenski jezikoslovni sceni žal realnost, saj prevladuje formalističen, sistemski pogled na jezik. Moja izkušnja iz Anglije je, da raziskave stimuliraš z rednim srečevanjem in debato. Mogoče bi bilo treba imeti recimo sociolingvistični krožek, kjer bi se lahko pogovarjali o delu na tem področju. Vsekakor ni nujno, da vsakič nekdo predstavi neko svojo lastno raziskavo, ker jih seveda toliko na leto ni. Kdaj se lahko skupaj prebere kakšen članek, ki je ravno izšel in se o njem predebatira. To je zelo pomembno zato, da se tudi študenti recimo priključijo, da se tudi njih motivira in se ta prostor tudi malo odpre. Je pa to tudi čisto praktična rešitev: takšne govorjene stvari so večinoma manj intenzivne, kot pa recimo pisanje in urejanje knjig, člankov, zbornikov in podobnih stvari. Torej to je praktična rešitev, da porabiš za debato recimo tri ure namesto 500 ur, kot jih potrebuješ, da pripraviš in izdaš neko knjigo. Taka knjiga bo seveda takoj zgolj ena na deset let. To bi samo dodal, da bi bilo takšno bolj redno srečevanje tukaj res potrebno.

Albina Nećak Lük: Zelo pozdravljam predlog kolega Savskega in mislim, da zdaj imamo mlade moči, ki bi mogoče bile voljne spet spraviti v pogon takšna srečanja, mogoče prav v okviru Društva za uporabno jezikoslovje. To društvo še vedno živi, čeprav na papirju, in plačuje redno članarino, tako da je Slovenija ostala članica Mednarodne zveze za uporabno jezikoslovje. Ta prireja srečanja s sociolingvistično tematiko. Ugodno je tudi to, da za njihove dogodke 
lahko dobite znižano kotizacijo in mogoče celo kakšno podporo za svojo aktivnost. Če je med vami oziroma v tem krogu kdo, ki bi bil pripravljen pomagati poživiti delovanje in organizirati takšna srečanja, bi to bilo mogoče. Jaz bi to podprla in bi tudi spodbudila odgovorne, da pripravijo srečanje, mogoče občni zbor, da se spet vzpostavi program in oživi delovanje društva. Je pa to vedno težko. Tudi dokler je društvo še delovalo, smo zelo agitirali, kot se je takrat lepo reklo, da so ljudje bili aktivni, vsaj kolikor toliko.

Nataša Logar: Zahvaljujem se vam za predstavitve. Odprli ste številne vidike sociolingvistike, ki jih do zdaj sploh nisem poznala. Omenili ste nek večji kongres. Katerega že?

Albina Nećak Lük: 24. sociolingvistični simpozij v Gentu.

Nataša Logar: Moj predlog je naslednji: naj gre kdo od vas ali od kolegov, ki se nam danes niso utegnili pridružiti, v Gent in po kongresu na temu podobnem srečanju poroča o aktualnih temah. Tako bi hitro ugotovili, kako se tudi pri nas lahko s čim manj zamude pridružimo evropskim trendom.

Maja Bitenc: Kot je bilo rečeno, je že samo načrtovanje projekt in bi moralo biti proces. Zdi se mi, da tu ne gre drugače kot z nadaljnjim tovrstnim srečevanjem in pogovarjanjem in da tudi enkratna številka Slavistične revije ne bo prinesla življenja, če ne bo odnosov in idej, ki se bodo razvijale in enkrat mogoče meso postale. Mislim pa, da je v vsakem primeru potrebno začeti od spodaj in na terenu, kvalitativno, pri tem pa upoštevati, kar je že bilo narejeno. Zdi se mi namreč, da je bila težava omenjene raziskave in še mnogokatere druge o jezikovnih stališčih in jezikovni rabi, da so rezultati na podlagi samoocen in njihova verodostojnost res zelo vprašljivi. Po tem, ko intervjuvaš ljudi in vidiš, s katerimi izrazi operirajo za katere varietete, ki jih uporabljajo oni ali njihovi bližnji in ki jih imaš na posnetku v avtentični, vsakodnevni komunikaciji, vidiš, da so tukaj res lahko prepadi vmes in da potem taka, pa še tako kvantitativna in obsežna raziskava ne pove veliko - res prazni so lahko ti rezultati. Tako se mi zdi, da mora biti izhodišče pri posamezniku, pri vsakodnevni komunikaciji, pri avtentični jezikovni rabi, pri dejanski analizi posnetkov, pa kakorkoli je mučna. In v kombinaciji različnih pristopov, saj vsaka metoda nekaj doprinese, samo v prepletanju različnih pa lahko pridemo do verodostojnih, merodajnih podatkov o stanju stvari. 
Karmen Kenda-Jež: Samo po drugi strani sva pa tudi midve ves čas ugotavljali, da dokler ni to delo timsko, taka raziskava ves čas ostaja nekakšen sondažni projekt. Torej, dokler nimaš možnosti, da jo opraviš v večjem obsegu.

Nataša Gliha Komac: Meni je prišlo na misel, da imamo zdaj na Inštitutu za slovenski jezik Frana Ramovša ZRC SAZU odličen fonolaboratorij in s tem možnost za kontinuirano spremljanje govorjenega jezika, zbiranje posnetkov in tako naprej - tudi to je pravzaprav ideja profesorice Albine Nećak Lük. Ampak tu je res treba, da se združi skupina strokovnjakov, da razmisli, kaj se da narediti, kako. Če so na voljo tako dobra tehnološka orodja, je škoda, da se jih ne uporabi.

Zato se mi zdi, da bi bilo dragoceno, da se posveti, kot je današnji, na nek način nadaljujejo. Mogoče vsebinsko bolj zamejeni: kaj koga posebej zanima, da se pač združi, pokliče, povabi na posamezno srečanje ljudi, raziskovalce, ki se ukvarjajo s točno določeno tematiko. Zgolj ideja.

Kot je omenila profesorica Albina Nećak Lük, pri japonskem projektu kontinuirano spremljajo stanje govorjenega jezika že od 5o. let dalje. Tudi za slovenski jezik bi bilo nekaj takega izjemno dragoceno in zdi se mi, da imamo nekatere možnosti že na voljo.

A pri takih stvareh je izjemno pomembno sodelovanje. Zame je (bila) zelo dragocena izkušnja tako pedagoškega dela na različnih fakultetah, Podiplomski šoli ZRC SAZU kot raziskovanja na ISJ FR ZRC SAZU. In za organizacijo tako velikih in dolgoročnih projektov je potrebno veliko ljudi in znanja, a tudi veliko dobre volje in predanosti, vrsta drobnih stvari in dejavnosti, nekdo mora iskati finance in načrtovati ipd. Na fakultetah se npr. srečujete z mladimi ljudmi, ki jih zanimajo različne stvari in še iščejo svojo pot, na inštitutih oz. pri nas so interesi že precej izoblikovani in raziskovalne poti zastavljene, zato včasih težje najdemo mlade ljudi, ki jih zanimajo določena področja. Npr. kdaj veš, da neko raziskovalno vprašanje je, je zelo zanimivo in pomembno, želel bi ga (dobro) raziskati, a moraš preprosto slediti zastavljenim projektom, omejen si z že zastavljenimi temeljnimi dejavnostmi in projekti, ki se trenutno izvajajo. In morda ne veš, da nekoga zanimajo enaka vprašanja, problematike, da ima neka znanja, da ima sposobnosti in morda ne možnosti za raziskovanje. Skupaj je včasih lažje najti pot. Tudi tovrstno sodelovanje je po moje pomembno. 
Marko Stabej: Jaz mislim, da kar omogoča Filozofska fakulteta, je pa to ravno tako možno na Inštitutu, kjer imate tudi vrsto različnih inštitutov, je to, da bi v ta forum ob določenih vprašanjih že v tem snovanju vključili tudi ljudi z drugih področji. Ne samo zato, da od njih nekaj izveš, ampak da se jih vključi v proces. Ker tukaj se mi zdi, da je dejansko zelo slabo poskrbljeno za to, tudi prej, ko je kakšna stvar bolje delovala, konkretno recimo Društvo za uporabno jezikoslovje, ki je bilo zelo živahno nekaj časa, ni bilo te izmenjave med različnimi strokami. Tukaj pa sta tako Filozofska fakulteta kot Inštitut možnost prostora, kjer ti ciljno vabiš določene ljudi v določene debate.

Marija Sotnikova Štravs: Jaz bi se na ta pogovor navezala samo kot nekdo, ki se ukvarja s sociolingvistiko in jezikovno politiko iz ljubezni do področja. Potem ko se poklicno ukvarjaš z nečim drugim, ostaneš izven vseh teh okvirjev in ti vse skupaj ostane bolj v smislu nekih občasnih debat ali pa kakšnih razprav na Facebooku. Samo toliko, kot mnenje z drugega pola - tudi za nekoga takšnega, kot sem jaz, bi ta prostor debate prišel prav, da nisi potem sam in se ne počutiš izoliranega.

Maja Bitenc: Očitno nek interes po pogovarjanju, načrtovanju in raziskovanju je, tako da bi morda res dorekli, da se srečamo še kdaj. Mogoče bi si kot izhodišče vsakič izbrali določeno temo, lahko kakšno delo, članek, monografijo - da bi vnaprej pregledali gradivo in potem skupaj razpravljali. Tisti, ki ste zainteresirani, pošljite na moj elektronski naslov sporočilo, da vas vključimo v skupino.

Marko Stabej: Najlepša hvala vsem prisotnim na vse načine. V upanju na nadaljnje sodelovanje ...

Albina Nećak Lük: ... na dolgo, čudovito prijateljstvo. 